\title{
Inhibition of IL-1 $\beta$ Signaling Normalizes NMDA-Dependent Neurotransmission and Reduces Seizure Susceptibility in a Mouse Model of Creutzfeldt-Jakob Disease
}

\author{
-Ilaria Bertani, ${ }^{1 *}$ - Valentina Iori, ${ }^{1 *}$ - Massimo Trusel, ${ }^{2 *}$ Mattia Maroso, ${ }^{1}$ CClaudia Foray, ${ }^{1}$ @Susanna Mantovani, ${ }^{1}$ \\ Raffaella Tonini, ${ }^{2}$ (D)Annamaria Vezzani, ${ }^{1}$ and ${ }^{\circ}$ Roberto Chiesa ${ }^{1}$ \\ ${ }^{1}$ Department of Neuroscience, Istituto di Ricovero e Cura a Carattere Scientifico-Istituto di Ricerche Farmacologiche Mario Negri, 20156 Milan, Italy, and \\ ${ }^{2}$ Neuroscience and Brain Technologies Department, Istituto Italiano di Tecnologia, 16163 Genoa, Italy
}

Creutzfeldt-Jakob disease (CJD) is a neurodegenerative disorder caused by prion protein (PrP) misfolding, clinically recognized by cognitive and motor deficits, electroencephalographic abnormalities, and seizures. Its neurophysiological bases are not known. To assess the potential involvement of NMDA receptor (NMDAR) dysfunction, we analyzed NMDA-dependent synaptic plasticity in hippocampal slices from $\operatorname{Tg}(\mathrm{CJD})$ mice, which model a genetic form of CJD. Because PrP depletion may result in functional upregulation of NMDARs, we also analyzed PrP knock-out (KO) mice. Long-term potentiation (LTP) at the Schaffer collateral-commissural synapses in the CA1 area of $\sim 100$-d-old $\operatorname{Tg}(\mathrm{CJD})$ mice was comparable to that of wild-type (WT) controls, but there was an inversion of metaplasticity, with increased GluN2B phosphorylation, which is indicative of enhanced NMDAR activation. Similar but less marked changes were seen in PrP KO mice. At $\sim 300 \mathrm{~d}$ of age, the magnitude of LTP increased in $\operatorname{Tg}(\mathrm{CJD})$ mice but decreased in PrP KO mice, indicating divergent changes in hippocampal synaptic responsiveness. $\operatorname{Tg}(\mathrm{CJD})$ but not PrP KO mice were intrinsically more susceptible than WT controls to focal hippocampal seizures induced by kainic acid. IL- $1 \beta$-positive astrocytes increased in the $\operatorname{Tg}(\mathrm{CJD})$ hippocampus, and blocking IL- 1 receptor signaling restored normal synaptic responses and reduced seizure susceptibility. These results indicate that alterations in NMDA-dependent glutamatergic transmission in $\operatorname{Tg}(\mathrm{CJD})$ mice do not depend solely on PrP functional loss. Moreover, astrocytic IL-1 $\beta$ plays a role in the enhanced synaptic responsiveness and seizure susceptibility, suggesting that targeting IL- $1 \beta$ signaling may offer a novel symptomatic treatment for CJD.

Key words: Creutzfeldt-Jakob disease; IL-1 receptor antagonist; prion; seizures; synaptic plasticity; transgenic mice

Significance Statement

Dementia and myoclonic jerks develop in individuals with Creutzfeldt-Jakob disease (CJD), an incurable brain disorder caused by alterations in prion protein structure. These individuals are prone to seizures and have high brain levels of the inflammatory cytokine IL-1 $\beta$. Here we show that blocking IL- $1 \beta$ receptors with anakinra, the human recombinant form of the endogenous IL-1 receptor antagonist used to treat rheumatoid arthritis, normalizes hippocampal neurotransmission and reduces seizure susceptibility in a CJD mouse model. These results link neuroinflammation to defective neurotransmission and the enhanced susceptibility to seizures in CJD and raise the possibility that targeting IL-1 $\beta$ with clinically available drugs may be beneficial for symptomatic treatment of the disease.

\section{Introduction}

Prion diseases are invariably fatal neurodegenerative disorders of humans and other mammals caused by misfolding of the cellular

Received May 5, 2017; revised July 31, 2017; accepted Aug. 23, 2017.

Author contributions: R.T., A.V., and R.C. designed research; I.B., V.I., M.T., M.M., C.F., and S.M. performed research; I.B., V.I., M.T., M.M., C.F., R.T., A.V., and R.C. analyzed data; A.V., R.T., and R.C. wrote the paper.

This work was supported by grants from Telethon-Italy (GGP12115), Fondazione Cariplo (2012-0560), the Italian Ministry of Health (RF-2010-2314035), the European Union Seventh Framework Programme (FP7/2007-2013) under grant agreement no. 602102 (EPITARGET), and the Fondazione Istituto Italiano di Tecnologia.

*I.B., V.I., and M.T. contributed equally to this work. prion protein $\left(\mathrm{PrP}^{\mathrm{C}}\right)$, a cell surface glycoprotein of uncertain function (Chiesa, 2015). Creutzfeldt-Jakob disease (CJD) is the most common form in humans. It can arise sporadically, be dominantly inherited due to mutations in the PRNP gene encoding $\operatorname{PrP}^{\mathrm{C}}$, or acquired by contact with exogenous $\operatorname{PrP}^{\mathrm{Sc}}$, the infec-

The authors declare no competing financial interests.

Correspondence should be addressed to Roberto Chiesa, Department of Neuroscience, IRCCS—Istituto di Ricerche Farmacologiche Mario Negri, Via G. La Masa 19, 20156 Milan, Italy. E-mail: roberto.chiesa@marionegri.it. DOI:10.1523/JNEUROSCI.1301-17.2017

Copyright $\odot 2017$ the authors $\quad 0270-6474 / 17 / 3710278-12 \$ 15.00 / 0$ 
tious $\mathrm{PrP}$ isoform (prion), which propagates by inducing misfolding of host-encoded $\operatorname{PrP}^{\mathrm{C}}$ (Colby and Prusiner, 2011; Head and Ironside, 2012).

CJD has a stereotyped clinical course. Altered mental function is the initial manifestation, including dementia, confusion, disorientation, behavior abnormalities, and depression of other higher cortical functions. Later, myoclonic jerks, rigidity, and extrapyramidal and cerebellar abnormalities become prominent.

In about two-thirds of patients, electroencephalography (EEG) detects typical periodic sharp wave complexes (PSWCs), either lateralized or generalized (Wieser et al., 2006). Epileptiform discharges and focal motor or generalized seizures may also be observed, typically in the late stage of the disease (Wieser et al., 2006). Nonconvulsive status epilepticus is sometimes a presenting symptom in CJD (Espinosa et al., 2010). This suggests that changes in neuronal network excitability occur in seizure-prone brain areas. As the patients near death, they become akinetic, unresponsive, mute, and rigid (Head and Ironside, 2012; Puoti et al., 2012).

The pathogenic mechanisms responsible for this complex symptomatology are not known. Studies in animal models have suggested several toxic mechanisms activated by abnormally folded PrP that may lead to neuronal dysfunction and death, including corruption of NMDA receptor (NMDAR) activity (Chiesa, 2015). Increased NMDAR-dependent excitation has been reported in mice inoculated with variant (v) CJD prions (Ratté et al., 2008), and when $\mathrm{PrP}^{\mathrm{Sc}}$, or the $\mathrm{PrP}^{\mathrm{Sc}}$-like $\mathrm{PrP} 106-126$ peptide, was exogenously presented to cultured neurons, NMDAR antagonists blocked the resulting neurotoxicity (Müller et al., 1993; Perovic et al., 1995; Brown et al., 1997; Resenberger et al., 2011; Thellung et al., 2013).

Loss of a physiological $\operatorname{PrP}^{\mathrm{C}}$ function in regulating NMDAR activity may also contribute to the pathogenic process. Genetic $\mathrm{PrP}^{\mathrm{C}}$ depletion results in increased hippocampal NMDARmediated excitation and glutamate exicitotoxicity (Khosravani et al., 2008). In addition, PrP knock-out (KO) mice are reported to be more susceptible to seizures induced by kainic acid (KA) than wild-type (WT) controls (Walz et al., 1999; Rangel et al., 2007), perhaps because of facilitated NMDAR-mediated excitation in the hippocampus (Maglio et al., 2004; Rangel et al., 2009); although this issue remains controversial (Striebel et al., 2013b; Carulla et al., 2015).

Deposition of misfolded/aggregated $\mathrm{PrP}$ and astrogliosis and microgliosis are typical neuropathological changes in CJD (Sikorska et al., 2012). In addition, CJD brains have high levels of several inflammatory cytokines, including interleukin-1 $\beta$ (IL-1 $\beta$; Sharief et al., 1999; Shi et al., 2013; Llorens et al., 2014). However, it is not clear which cell population is responsible for the increase in IL- $1 \beta$ and whether this proinflammatory cytokine contributes to enhancing NMDAR-mediated glutamatergic transmission (Viviani et al., 2003; Balosso et al., 2008), lowering the threshold for seizures (Vezzani and Viviani, 2015).

We previously generated $\mathrm{Tg}(\mathrm{CJD})$ mice expressing the mouse (mo) PrP homolog of the D178N/V129 mutation linked to genetic CJD (Dossena et al., 2008). These mice synthesize a misfolded form of mutant $\operatorname{PrP}$ in their brains and develop clinical and neuropathological features highly reminiscent of CJD, including memory and motor deficits, abnormal EEG patterns mimicking the human PSWCs, PrP deposition and gliosis (Dossena et al., 2008).

The present study provides evidence of dysfunctional NMDAdependent hippocampal synaptic plasticity and enhanced seizure susceptibility in $\operatorname{Tg}(\mathrm{CJD})$ mice, resulting from a com- bination of loss and gain of function of mutant PrP, exacerbated by neuroinflammation.

\section{Materials and Methods}

Experimental design and statistical analysis. All animal experiments were designed in accordance with the ARRIVE (Animal Research: Reporting of In Vivo Experiments) guidelines (Kilkenny et al., 2010), with a commitment to refinement, reduction, and replacement, minimizing the numbers of mice, while using biostatistics to optimize mouse numbers (as used in our previously published peer-reviewed work: Nazzaro et al., 2012; Bouybayoune et al., 2015; Trusel et al., 2015; Iori et al., 2017). Thus, for statistical validity, we used 5-10 mice for electrophysiology, 6-10 mice for analysis of KA-induced seizures, and 4-10 mice for reverse transcription quantitative real-time PCR (qRT-PCR), biochemical analysis, and histology (the number of mice used in each experiment is reported in the figure legends). No sex-related differences in the $\operatorname{Tg}(\mathrm{CJD})$ phenotype were observed, so both male and female mice were used for qRT-PCR, biochemistry, and histology. Males were used for electrophysiology and analysis of hippocampal seizures to avoid variations due to ovarian cycles in females (Mejías-Aponte et al., 2002; Twele et al., 2016). Simple randomization was used for treatment allocation. Blinding was applied to treatment administration and data analysis.

For each variable, differences between the groups were assessed using independent-samples Student's $t$ test, one-way ANOVA, and two-way ANOVA (genotype and/or drug treatment as independent factors) followed by Tukey's, Mann-Whitney, or Holm-Sidak post hoc analysis when appropriate (details are reported in the figure legends). Synaptic plasticity data were analyzed with one-way ANOVA for repeated measures (RM1W) or two-way ANOVA for repeated measures (RM2W) followed by Tukey's post hoc analysis; $n$ indicates number of recordings.

Mice. Production of Tg(CJD) mice, expressing moPrP D177N/V128 tagged with an epitope for monoclonal antibody $3 \mathrm{~F} 4$ has already been reported (Dossena et al., 2008). We used mice of the $\operatorname{Tg}\left(\mathrm{CJD}-\mathrm{A} 21^{+/-}\right)$)/ Prnp $^{0 / 0}$ line expressing 3F4-tagged D177N/V128 PrP at $\sim 1 \times$ that had been backcrossed for $>10$ generations with an inbred colony of Zürich I $\operatorname{Prnp}{ }^{0 / 0}$ mice (Büeler et al., 1992) with a pure C57BL/6J background (C57BL/6J/Prnp ${ }^{0 / 0}$; European Mouse Mutant Archive, Monterotondo, Rome, Italy; RRID:IMSR_EM:01723). The status of the transgene was determined by PCR (Dossena et al., 2008). PrP KO mice were nontransgenic littermates of $\mathrm{Tg}\left(\mathrm{CJD}-\mathrm{A} 21^{+/-}\right) / \operatorname{Prnp}^{0 / 0}$ mice. Age-matched C57BL/6J (WT) mice were purchased from Envigo (http://www.envigo. com/products-services/research-models-services/models/research-models/ mice/inbred/c57bl-6-inbred-mice/c57bl-6jrcchsd/). Mice were housed at constant room temperature $\left(\mathrm{RT} ; 23^{\circ} \mathrm{C}\right)$ and relative humidity $(60 \pm 5 \%)$ with free access to food and water and a fixed $12 \mathrm{~h}$ light/dark cycle. To reduce experimental variability due to different husbandry conditions, WT mice purchased from Envigo were housed in the same animal room as $\operatorname{Tg}(\mathrm{CJD})$ and PrP KO mice for from at least 2 weeks to several months.

Procedures involving animals and their care were conducted in conformity with the institutional guidelines at the IRCCS (Istituto di Ricovero e Cura a Carattere Scientifico)-Mario Negri Institute for Pharmacological Research in compliance with national (D.lgs 26/2014; Authorization no. 19/2008-A issued March 6, 2008 by the Ministry of Health of Italy) and international laws and policies (European Economic Community Council Directive 2010/63/UE; the National Institutes of Health Guide for the Care and Use of Laboratory Animals, 2011 edition). They were reviewed and approved by the Mario Negri Institute Animal Care and Use Committee, which includes ad hoc members for ethical issues, and by the Italian Ministry of Health (Decreto no. 62/2012-B and 212/2016-PR). Animal facilities meet international standards and are regularly checked by a certified veterinarian who is responsible for health monitoring, animal welfare supervision, experimental protocols, and review of procedures.

Determination of NMDARs on postsynaptic density. Subcellular fractionation of the mouse hippocampus was as described previously (Balducci et al., 2010). Tissue was homogenized in ice-cold $0.32 \mathrm{~m}$ sucrose containing $1 \mathrm{~mm}$ HEPES, $1 \mathrm{~mm} \mathrm{MgCl}, 1 \mathrm{mM} \mathrm{NaHCO}_{3}$, and $0.1 \mathrm{~mm}$ PMSF, at pH 7.4, with a complete set of protease inhibitors (SigmaFast, Sigma-Aldrich) and phosphatase inhibitors (PhosSTOP, Roche Life 
Science). The homogenized tissue was centrifuged at $1000 \times g$ for $5 \mathrm{~min}$ and the supernatant was centrifuged at $13,000 \times g$ for $15 \mathrm{~min}$ to obtain a crude membrane fraction. The pellet was then resuspended in $1 \mathrm{~mm}$ HEPES containing protease and phosphatase inhibitors and was centrifuged at $100,000 \times \mathrm{g}$ for $1 \mathrm{~h}$. The resulting pellet was resuspended in a buffer containing $75 \mathrm{~mm} \mathrm{KCl}$, protease, and phosphatase inhibitors and $1 \%$ Triton X-100 and centrifuged at 100,000 $\times g$ for $1 \mathrm{~h}$. The final pellet was homogenized in a glass-glass Potter homogenizer in 20 mM HEPES with protease and phosphatase inhibitors; this fraction, referred to as the Triton-insoluble fraction, was stored at $-80^{\circ} \mathrm{C}$. The protein composition of this preparation was tested for the absence of the presynaptic marker synaptophysin and enrichment in postsynaptic density (PSD) proteins. Proteins $(10 \mu \mathrm{g})$ were resolved by SDS PAGE and electrophoretically transferred to polyvinylidene fluoride membranes. The membranes were blocked for $1 \mathrm{~h}$ in $5 \%$ nonfat dry milk in Tris-buffered saline $0.1 \mathrm{M}, \mathrm{pH}$ 7.4, containing $0.01 \%$ Tween 20 (TTBS), then incubated with the primary antibody diluted in blocking solution, with the exception of antiphospho-Tyr1472 GluN2B, which was diluted in TTBS containing 5\% bovine serum albumin (BSA). The antibodies were as follows: mouse monoclonal anti-GluN1 (1:1000; Synaptic Systems; RRID:AB_2113443), rabbit polyclonal anti-phospho-Tyr 1472 GluN2B (1:700; Thermo Fisher Scientific; RRID:AB_325370), rabbit polyclonal anti-GluN2A (1:2000; Invitrogen; RRID:AB_2536209), anti-GluN2B (1:2000; Invitrogen; RRID:AB_2536210), mouse monoclonal anti-PSD95 (1:10,000; NeuroMab; RRID:AB_10698024), and mouse monoclonal anti- $\beta$-actin (1: 20,000; Millipore; RRID:AB_2223041). After thorough rinsing in TTBS, the blots were incubated with horseradish peroxidase-conjugated secondary antibodies, revealed using enhanced chemiluminescence (Luminata Forte, Millipore) and visualized by a BIO-RAD XRS Image Scanner. Quantity-One software (BIO-RAD) was used for quantitative densitometry of protein bands.

Histology. Mice were deeply anesthetized by intraperitoneal injection of $100 \mathrm{mg} / \mathrm{kg}$ ketamine hydrochloride and $1 \mathrm{mg} / \mathrm{kg}$ medetomidine hydrochloride (Alcyon) and perfused through the ascending aorta with PBS $(0.05 \mathrm{M}), \mathrm{pH} 7.4$, followed by $4 \%$ paraformaldehyde in PBS. Brains were removed, postfixed, cryoprotected, and frozen at $-80^{\circ} \mathrm{C}$. Sections were cut throughout the septotemporal aspects of the hippocampus using a Leica cryostat and incubated for $1 \mathrm{~h}$ at RT with $10 \%$ normal goat serum, $1 \%$ Triton X-100 in Tris-buffered saline $0.1 \mathrm{M}, \mathrm{pH} 7.4$, then overnight at $4^{\circ} \mathrm{C}$ with rabbit polyclonal anti-glial fibrillary acid protein (GFAP) antibody (1:2500; Dako; RRID:AB_10013382), rat polyclonal anti-CD11b (1:1000; Serotec; RRID:AB_321292), and goat polyclonal anti-IL-1 $\beta$ (1:200; Santa Cruz Biotechnology; RRID:AB_2124627), followed by visualization with the Vectastain $\mathrm{ABC}$ kit (Vector Laboratories), with diaminobenzidine (DAB; or nickel-intensified DAB for IL-1 $\beta$ ) as chromogen. The TSA Cyanine 5 System (PerkinElmer) was used for immunofluorescent staining of IL-1 $\beta$. Anti-rat (RRID:AB_141709) and anti-rabbit IgG Alexa Fluor 488 (1:500; Invitrogen; RRID:AB_143165) were used for immunofluorescent staining of CD11b and GFAP, respectively. Sections were reacted with $2 \mu \mathrm{g} / \mathrm{ml}$ Hoechst 33258 stain (Molecular Probes; RRID:AB_2651133) to stain the nuclei. Slices were matched at comparable anteroposterior and dorsoventral levels for comparison of the different experimental groups.

Reverse transcription $q R T-P C R$. Total RNA from the mouse hippocampus was extracted using the SV Total RNA Isolation System (Promega) according to the manufacturer instructions; $1-2 \mu \mathrm{g}$ of RNA was reverse transcribed with the High-Capacity cDNA Kit (Life Technologies), and cDNA was amplified by a 7900 HT Sequence Detection System (Life Technologies). Samples were always processed in triplicate. The relative gene expression was calculated by the formula $2^{(-\Delta \Delta \mathrm{Ct})}$ using a defined group as reference $\left(2^{(-\Delta \Delta \mathrm{Ct})}=1\right)$. The primer sequences were as follows: $5^{\prime}$-CTCCATGAGCTTTGTACAAGG-3' for IL- $1 \beta$ forward and $5^{\prime}$-TGCTGATGTACCAGTTGGGG-3' for IL- $1 \beta$ reverse; $5^{\prime}$-AGGTCG GTGTGAACGGATTTG-3' for GAPDH forward and $5^{\prime}$-TGTAGACCA TGTAGTAGTTGAGGTCA-3' for GAPDH reverse (De Simoni et al., 2000).

Electrophysiology. Male mice were anesthetized with isoflurane and decapitated, and their brains were transferred to ice-cold dissecting artificial CSF (aCSF) containing $87 \mathrm{~mm} \mathrm{NaCl}, 75 \mathrm{~mm}$ sucrose, $2.5 \mathrm{~mm} \mathrm{KCl}$,
$1.25 \mathrm{~mm} \mathrm{NaH}_{2} \mathrm{PO}_{4}, 7 \mathrm{~mm} \mathrm{MgCl}, 0.5 \mathrm{~mm} \mathrm{CaCl}_{2}, 25 \mathrm{~mm} \mathrm{NaHCO}_{3}$, and $25 \mathrm{~mm}$ d-glucose, saturated with $95 \% \mathrm{O}_{2}$ and $5 \% \mathrm{CO}_{2}$ (Balducci et al., 2010). Oblique coronal sections ( $350 \mu \mathrm{m}$ thick) were cut using a Vibratome 1000S Slicer (Leica), then transferred to aCSF containing 115 mм NaCl, $3.5 \mathrm{~mm} \mathrm{KCl}, 1.2 \mathrm{~mm} \mathrm{NaH}_{2} \mathrm{PO}_{4}, 1.3 \mathrm{~mm} \mathrm{MgCl}_{2}, 2 \mathrm{~mm} \mathrm{CaCl}_{2}, 25$ mM $\mathrm{NaHCO}_{3}$, and $25 \mathrm{~mm}$ D-glucose and aerated with $95 \% \mathrm{O}_{2}$ and $5 \%$ $\mathrm{CO}_{2}$. After $15 \mathrm{~min}$ at $32^{\circ} \mathrm{C}$, slices were kept at $22-24^{\circ} \mathrm{C}$. During experiments, slices were continuously superfused with aCSF at a rate of $2 \mathrm{ml} /$ $\min$ at $28^{\circ} \mathrm{C}$.

Extracellular recordings of field postsynaptic potentials (fPSPs) were obtained in the CA1 stratum radiatum, using glass micropipettes filled with aCSF. Stimuli (50-160 $\mu \mathrm{A}, 50 \mu \mathrm{s})$ to excite Shaffer collaterals were delivered through a bipolar twisted tungsten electrode placed $400 \mu \mathrm{m}$ from the recording electrode. Long-term potentiation (LTP) was induced using the following theta burst stimulation (TBS) protocol: 10 trains (4 pulses at $100 \mathrm{~Hz}$ ) at $5 \mathrm{~Hz}$, repeated twice with a 2 min interval. To induce metaplasticity, we applied a priming low-frequency stimulation (LFS) protocol (10 Hz, 10 pulses repeated twice, separated by $1 \mathrm{~s}$ ) delivered 25 min before TBS (Costello et al., 2012). The magnitude of synaptic plasticity was evaluated by comparing the fPSP normalized slopes from the last $5 \mathrm{~min}$ of baseline recordings with those 18-26 min after LFS or 35-45 min after TBS planned comparison.

Mouse model of seizures. Male mice (6-10) were surgically implanted under general gas anesthesia $\left(1-3 \%\right.$ isoflurane in $\left.\mathrm{O}_{2}\right)$ and stereotaxic guidance (Iori et al., 2013). Two nichrome-insulated bipolar depth electrodes (outer diameter, $60 \mu \mathrm{m}$ ) were implanted bilaterally into the dorsal hippocampus (from bregma: nose bar, $0 \mathrm{~mm}$; anteroposterior, $-1.8 \mathrm{~mm}$; lateral, 1.5 and $2.0 \mathrm{~mm}$ below dura mater). A 23-gauge cannula was unilaterally positioned on top of the dura mater and glued to one of the depth electrodes for the intrahippocampal injection of KA (Balosso et al., 2008; Iori et al., 2013, 2017). The electrodes were connected to a multipin socket and, together with the injection cannula, were secured to the skull with acrylic dental cement. KA (Sigma-Aldrich) was injected intrahippocampally in freely moving mice, $7 \mathrm{~d}$ after surgery (Iori et al., 2013). KA $7 \mathrm{ng}$ in $0.5 \mu \mathrm{l}$ was dissolved in $0.1 \mathrm{M} \mathrm{PBS}, \mathrm{pH} 7.4$, and injected unilaterally into the dorsal hippocampus in freely moving mice using a needle protruding $2.0 \mathrm{~mm}$ from the bottom of the guide cannula. The needle was left in place for 1 more minute to avoid backflow through the cannula. This dose of KA induces EEG ictal episodes in the hippocampus in $100 \%$ of mice with no mortality (Iori et al., 2013). Human recombinant IL-1 receptor antagonist (anakinra; Biovitrum) was diluted in sterile saline and bilaterally injected intracerebroventricularly $(0.5 \mu \mathrm{g} / 0.5 \mu \mathrm{l} / \mathrm{side})$ in mice, 10 min before KA. For injection of saline or anakinra, mice were implanted with two additional cannulae bilaterally on top of the dura mater.

EEG activity was recorded using the Twin EEG Recording System (version 4.5.3.23) connected with a Comet AS-40 32/8 Amplifier (sampling rate, $400 \mathrm{~Hz}$; high-pass filter, $0.3 \mathrm{~Hz}$; low-pass filter, $70 \mathrm{~Hz}$; sensitivity, $2000 \mathrm{mV} / \mathrm{cm}$; Grass-Telefactor). Digitized EEG data were processed using the Twin record and review software. EEG was recorded for $30 \mathrm{~min}$ before KA injection to assess baseline activity, and for $180 \mathrm{~min}$ after KA. At least one $30 \mathrm{~min}$ recording similar to baseline was required before ending the experiment.

Ictal episodes are characterized by high-frequency $(7-10 \mathrm{~Hz})$ and/or multispike complexes and/or high-voltage (700 $\mu \mathrm{V}$ to $1.0 \mathrm{mV})$ synchronized spikes occurring simultaneously in the injected and contralateral hippocampi. Seizure activity was quantified by measuring the number and total duration of seizures (summing up the duration of each ictal episode during the EEG recording). Seizures occurred with an average latency of $\sim 10 \mathrm{~min}$ from KA injection, then recurred for $\sim 120 \mathrm{~min}$, and were associated with motor arrest of the mice.

\section{Results}

$\mathrm{Tg}(\mathrm{CJD})$ mice show an inversion of synaptic metaplasticity associated with alterations in NMDAR composition

The $\operatorname{Tg}(\mathrm{CJD})$ mice we used express mutant PrP at a level similar to that of endogenous PrP in WT mice, on a PrP KO genetic background (C57BL/6J/Prnp ${ }^{0 / 0}$ ); therefore, they express trans- 
A

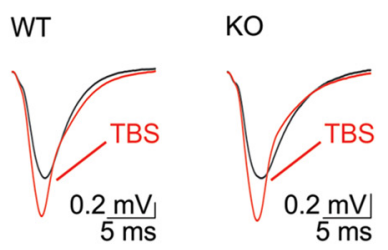

CJD
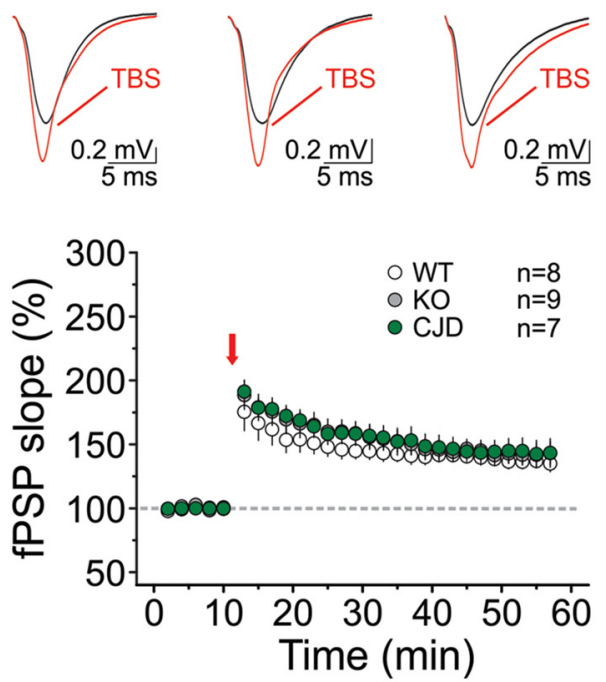

B

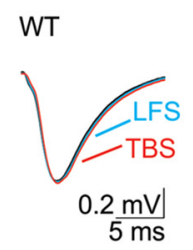

$\mathrm{KO}$

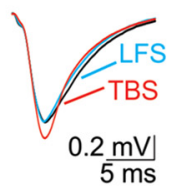

CJD

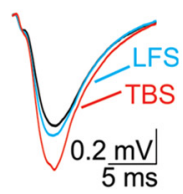

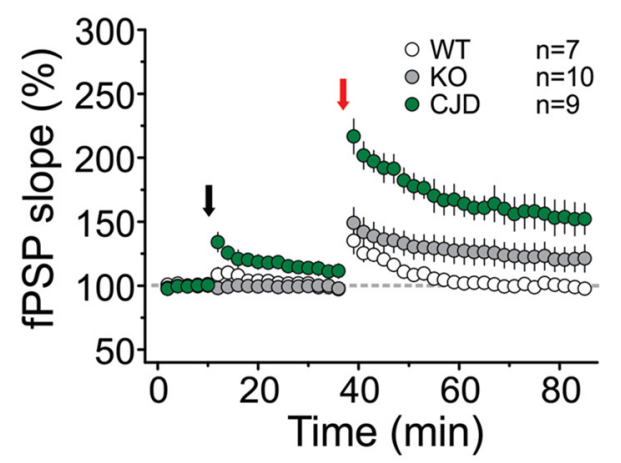

Figure 1. Young adult $\mathrm{Tg}(\mathrm{CD})$ mice have normal hippocampal plasticity but abnormal metaplasticity. $A$, TBS of Schaffer collaterals induces significant LTP of fPSP responses in CA1 of $\sim 100-\mathrm{d}$-old WT mice (white circles; RM1W, $F_{(7,9)}=30, p=0.0003$; Tukey's test, $p<0.05$ ). LTP was similar in age-matched PrP K0 mice (gray circles; RM1W, $F_{(8,9)}=26, p=0.0004 ;$ Tukey's test, $p<0.05$ ) and Tg(CD) mice (green circles; RM1W, $F_{(6,9)}=18, p=0.005 ;$ Tukey's test, $p<0.05 ; \mathrm{RM} 2 \mathrm{~W}, F_{(2,21)}=0.7, p=0.7 ;$ WT vs (JD mice, $p>0.05$, Tukey's posthoc test). Insets, Superimposed averaged records (5 traces) from WT (left) PrP KO (center), and $\mathrm{Tg}(\mathrm{CJD})$ mice (right) before (gray line) and $35-45$ min after the TBS stimulation (red line). $B$, Preceding the TBS with a priming stimulation ( 2 trains of 10 pulses at $10 \mathrm{~Hz}$, spaced $1 \mathrm{~s}$ apart) prevented the LTP in WT mice (white circles; RM1W, $F_{(6,9)}=0.4, p=0.6$ ) but not in PrP K0 mice (gray circles; RM1W, $F_{(9,9)}=13, p=0.003 ;$ Tukey's test, $p<0.05)$ or $\mathrm{Tg}(\mathrm{CJD})$ mice (green circles; RM1W, $F_{(8,9)}=22, p=0.001$; Tukey's test, $p<0.05 ; \mathrm{RM} 2 \mathrm{~W}, F_{(2,23)}=0.9, p=0.5 ; \mathrm{WT}$ vs K0 mice, $p>0.05 ; \mathrm{WT}$ vs (JD mice, $p<0.001 ; \mathrm{K} 0$ vs CJD mice, $p<0.5$, Tukey's post hoc test). The priming stimulus did not significantly alter the fPSP slope in $\operatorname{Tg}(\mathrm{CDD})$ mice compared with controls (WT mice: $100 \pm 4 \%$ of baseline, 7 mice, RM1W, $F_{(6,8)}=0.5, p=0.5 ; \operatorname{PrP~K0}$ mice: $99 \pm 2 \%$ of baseline, 10 mice, RM1W, $F_{(9,8)}=0.2, p=0.7 ; \mathrm{Tg}(\mathrm{CDD})$ mice: $111 \pm 4 \%$ of baseline, 9 mice, RM1W, $F_{(8,9)}=7, p=0.02 ;$ Tukey's test, $p>0.05$; $\mathrm{RM} 2 \mathrm{~W}, F_{(2,23)}=1.0, p=0.5 ;$ WT vs PrP K0 mice, $p>0.05$; WT vs Tg(CD) mice, $p>0.05$, Tukey's post hoc test). Insets, Superimposed averaged records (5 traces) from WT (left) PrP K0 (center), and $\operatorname{Tg}(\mathrm{CJD})$ mice (right) before the priming stimulus (gray line), $18-26$ min after the low-frequency priming stimulus (LFS; blue line) and $35-45$ min after the TBS (red line). $\boldsymbol{A}, \boldsymbol{B}$, Averaged time courses (mean \pm SEM) of normalized fPSP slopes. TBS or LFS (in the metaplasticity experiments) was performed at the red and the black arrows, respectively. Dashed horizontal lines define baseline responses.

genic but not endogenous WT PrP (Dossena et al., 2008). They develop deficits in spatial working memory between 200 and $300 \mathrm{~d}$ of age; progressive motor dysfunction, first detectable in the accelerating Rotarod test between 300 and $350 \mathrm{~d}$; overt clinical signs, such as ataxia, kyphosis, and foot clasp reflex, by $\sim 450 \mathrm{~d}$; and die prematurely at $\sim 700 \mathrm{~d}$ (Dossena et al., 2008; Senatore et al., 2012).

We examined synaptic NMDA-dependent long-term plasticity at Schaffer collateral-commissural synapses in the CA1 area on ex vivo brain slices from presymptomatic $\sim 100$-d-old $\mathrm{Tg}(\mathrm{CJD})$ mice, nontransgenic $\operatorname{PrP}$ KO littermates, and age-matched C57BL/6J (WT) controls. We first examined the ability of CA3CA1 synapses to undergo LTP. TBS resulted in robust LTP in all groups of mice (WT mice, $134 \pm 6 \%$ of baseline; PrP KO mice, $143 \pm 8 \%$ of baseline; $\operatorname{Tg}(\mathrm{CJD})$ mice mice, $144 \pm 10 \%$ of baseline; $n=7-9, p<0.05$; Fig. $1 A$ ).

Preactivation of various intracellular signaling pathways before the delivery of a plasticity induction protocol can prime hippocampal synapses by modifying NMDAR activity (Blitzer et al., 1998; Lu et al., 1998; Huang et al., 2001). This priming inhibits the subsequent induction of LTP (MacDonald et al., 2006), a process conceptualized as synaptic metaplasticity (Hulme et al., 2013). When we investigated metaplasticity at CA3-CA1 synapses of WT mice, we found that a low-frequency $(10 \mathrm{~Hz})$ priming stimulus (LFS) did not change basal neurotransmission ( $p>$ 0.05 ) but prevented the LTP after TBS ( $100 \pm 3 \%$ of baseline; $n=$ $7 ; p>0.05$; Fig. $1 B$ ), which is consistent with previous findings (Balducci et al., 2010). As in WT mice, LFS priming did not significantly affect basal synaptic responsiveness in $\operatorname{Tg}(\mathrm{CJD})$ and PrP KO animals $(p>0.05)$ but failed to inhibit LTP induction in
$\operatorname{Tg}(\mathrm{CJD})$ mice $(152 \pm 11 \% ; n=9 ; p<0.05)$, and to a lesser extent in PrP KO mice ( $125 \pm 6 \% ; n=10$; $p<0.05$; Fig. $1 B$ ).

Hippocampal metaplasticity depends on changes in the localization and composition of postsynaptic NMDARs triggered by the priming stimulation (Christie et al., 1995; Gisabella et al., 2003). The inversion of metaplasticity in $\operatorname{Tg}(\mathrm{CJD})$ and $\mathrm{PrP} \mathrm{KO}$ mice raises the possibility that the composition of NMDARs may be constitutively altered in these mice, impairing further changes after priming. To test this, we analyzed NMDAR subunit composition in hippocampal PSD-enriched fractions by immunoblotting. We found no changes in the total levels of GluN2A, GluN2B, and GluN1, but found a significant increase in phospho-Tyr 1472 GluN2B in $\operatorname{Tg}(\mathrm{CJD})$ mice (Fig. 2), which is the phosphorylated isoform that potentiates NMDA-induced $\mathrm{Ca}^{2+}$ influx. The level of phospho-Tyr1472 GluN2B in PrP KO mice was intermediate between those of WT and $\mathrm{Tg}(\mathrm{CJD})$ mice (Fig. 2C).

These results indicate abnormal hippocampal NMDAR trafficking in the PSD fractions, with an increase in GluN2B synaptic expression in $\operatorname{Tg}(\mathrm{CJD})$ mice and, to a lesser extent, in $\mathrm{PrP} \mathrm{KO}$ mice. This correlates well with the impairment in synaptic metaplasticity, which is also more evident in $\operatorname{Tg}(\mathrm{CJD})$ mice.

$\operatorname{Tg}(\mathrm{CJD})$ mice show age-dependent increases in IL- $1 \beta$ levels in the hippocampus

There is evidence that IL- $1 \beta$ promotes Src family kinase (SFK)mediated Tyr1472 phosphorylation of GluN2B (Viviani et al., 2003), and its brain levels are high in CJD (Sharief et al., 1999; Shi et al., 2013; Llorens et al., 2014). We investigated IL-1 $\beta$ expression in the hippocampus of $\mathrm{Tg}(\mathrm{CJD})$ mice at presymptomatic $(60$ and $120 \mathrm{~d}$ ), early ( $240 \mathrm{~d})$, and advanced ( $>400 \mathrm{~d}$ ) symptomatic 
A

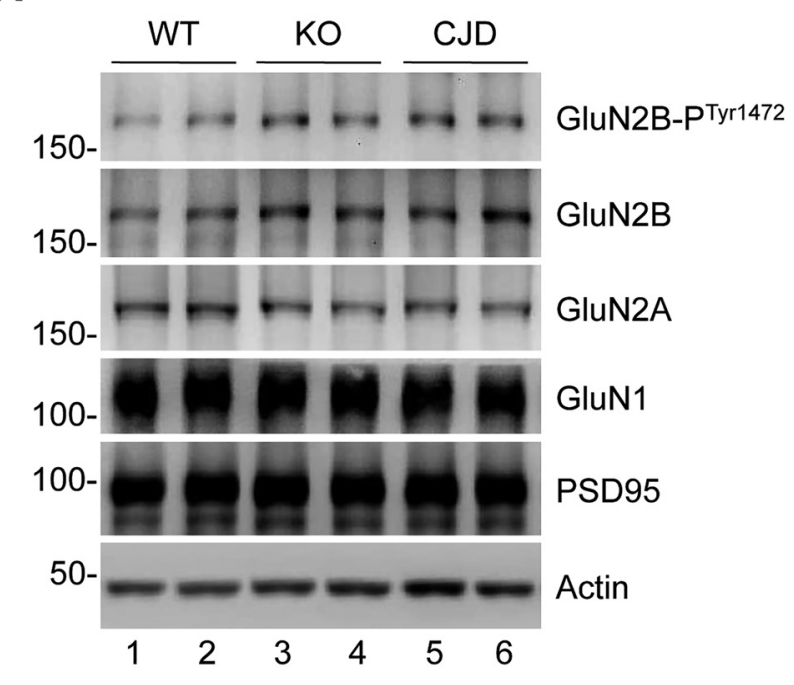

B

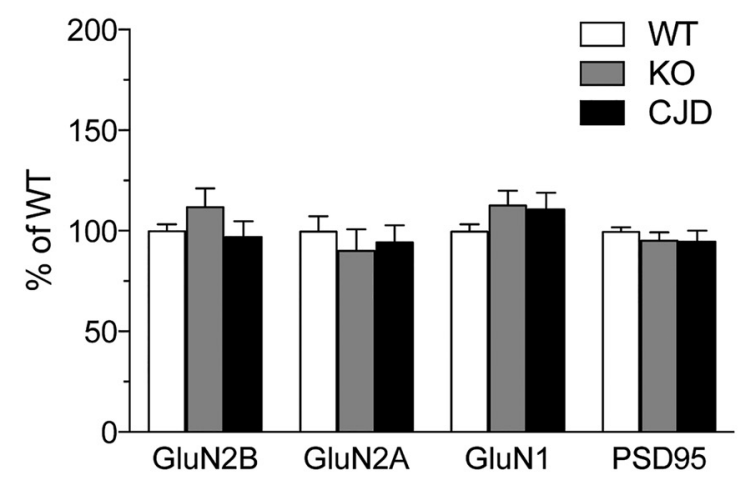

C

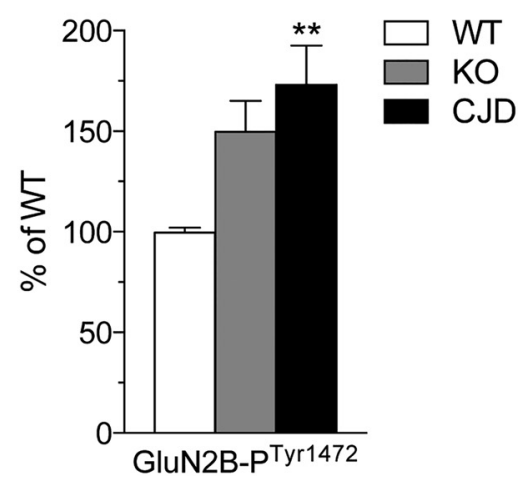

Figure 2. Increased phospho-Tyr GluN2B in hippocampal postsynaptic fractions of $\mathrm{Tg}(\mathrm{CJD})$ and PrP K0 mice. $\boldsymbol{A}$, Triton X-100-insoluble fractions representing the postsynaptic density were isolated from the hippocampi of WT, K0, and $\operatorname{Tg}(\mathrm{CJD})$ mice. Samples corresponding to $10 \mu \mathrm{g}$ of protein were analyzed by Western blot with the antibodies indicated. $\boldsymbol{B}$, The protein levels were quantified by densitometric analysis of Western blots, normalized for the level of actin and expressed as percentages of the level in WT mice. $C$, Tyrosine residue 1472 -phosphorylated GluN2B was normalized on total GluN2B and expressed as percentages of the level in WT mice. Data are the mean \pm SEM of $8-10$ animals at $65-80 \mathrm{~d}$ of age; $F_{(2,86)}=6.541, p=0.0023$ by one-way ANOVA; ${ }^{* *} p<0.01$ vs WT by Tukey's post hoc test.

stages of their illness (Dossena et al., 2008; Senatore et al., 2012). Immunohistochemistry with an anti-GFAP antibody confirmed the proliferation and hypertrophy of astrocytes previously documented in $\operatorname{Tg}($ CJD) mice (Dossena et al., 2008). Astrocytosis was already observed in the hippocampi of 60-d-old mice and increased with age (Fig. 3A). Staining with the microglial marker CD11b showed marked microglial activation already at $60 \mathrm{~d}$ of age (Fig. 3B).

IL- $1 \beta$-immunopositive cells were detected in the hippocampi of $\mathrm{Tg}(\mathrm{CJD})$ mice, but not in WT and PrP KO mice (Fig. 4A). There were gradually more of these cells in older $\operatorname{Tg}(\mathrm{CJD})$ mice (Fig. $4 B$ ). Coimmunofluorescent staining of IL- $1 \beta$ with GFAP, CD11b, or the neuronal marker NeuN (data not shown), showed that IL-1 $\beta$ was exclusively expressed by astrocytes (Fig. 4C). Quantitative RT-PCR showed a significant increase in IL-1 $\beta$ mRNA in the hippocampus of $\operatorname{Tg}(\mathrm{CJD})$ mice already at $60 \mathrm{~d}$ of age (Fig. 4D).

These results indicate proinflammatory changes in the hippocampi of $\mathrm{Tg}(\mathrm{CJD})$ mice starting from a presymptomatic stage. This proinflammatory milieu, and particularly IL- $1 \beta$ released from activated astrocytes, may promote neuronal GluN2B phosphorylation over the level induced by the loss of $\operatorname{PrP}$ function in
PrP KO mice. This may contribute to enhancing NMDAR activity in the mutant mice (Viviani et al., 2003).

The IL-1 receptor antagonist rescues the defect in hippocampal metaplasticity and the age-dependent increase in LTP in Tg(CJD) mice

IL- $1 \beta$ signaling participates in the regulation of synaptic plasticity in physiological and pathological conditions (Ross et al., 2003; Costello et al., 2011; Vezzani and Viviani, 2015). To investigate whether the age-dependent elevation of IL-1 $\beta$ in $\operatorname{Tg}(\mathrm{CJD})$ mice was associated with changes in hippocampal synaptic plasticity, we analyzed LTP and metaplasticity in $\sim 300$-d-old mice. TBS resulted in efficient LTP in WT mice (129 $\pm 5 \%$ of baseline; 10 mice; $p<0.01$; Fig. $5 A$ ). LTP was significantly reduced in slices from PrP KO mice ( $106 \pm 5 \% ; 13$ mice; $p>0.05$; Fig. $5 A$ ), which is consistent with the age-dependent impairment in LTP previously documented in these mice (Curtis et al., 2003). In contrast, TBS triggered a greater LTP in $\mathrm{Tg}(\mathrm{CJD})$ animals than in WT controls ( $171 \pm 12 \%$; 5 mice; $p<0.05$; Fig. $5 A$ ), indicating enhanced synaptic responsiveness.

When we examined synaptic metaplasticity, we found that the priming stimulus efficiently suppressed LTP in slices from WT 
A

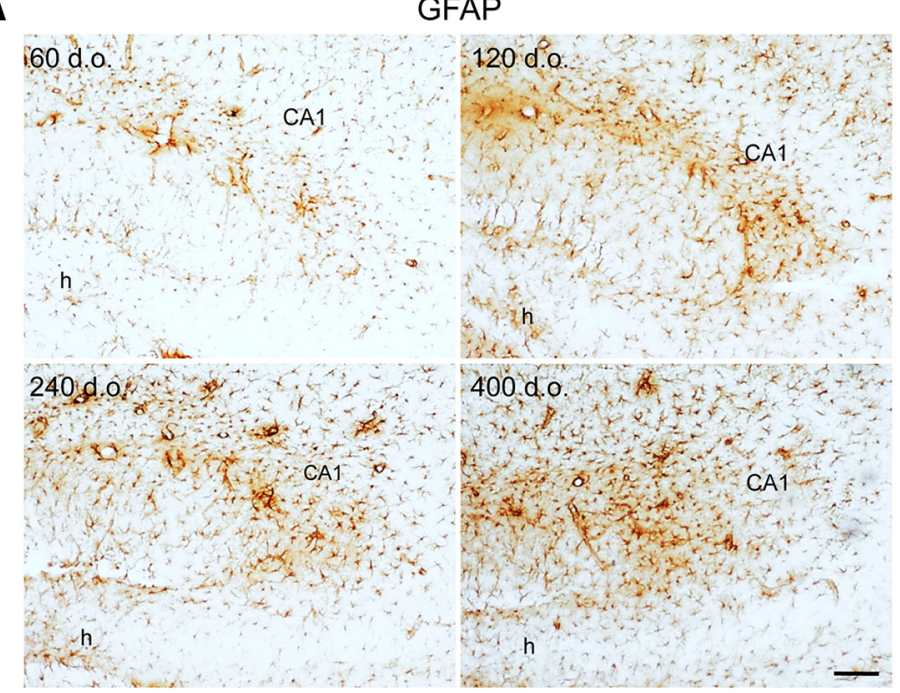

B

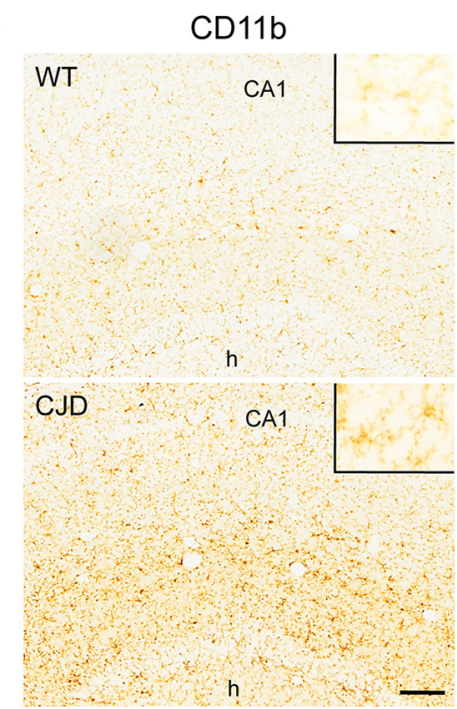

Figure 3. $\operatorname{Tg}(\mathrm{CJD})$ mice have proliferation of astrocytes and microglia in the hippocampus. $A$, Brain sections from $\operatorname{Tg}(\mathrm{CJD})$ mice at the ages indicated were stained with anti-GFAP antibody. Immunostaining revealed marked astrocytosis in the hippocampus. $\boldsymbol{B}$, Immunostaining with anti-CD11b shows marked microgliosis in the hippocampus of a $\operatorname{Tg}(C \mathrm{CD}) \mathrm{mouse}$ at $60 \mathrm{~d}$ of age compared with an age-matched WT control. Scale bars, $100 \mu \mathrm{m}$. CA1, Field CA1 of hippocampus; h, hilus of the dentate gyrus. Insets, High-magnification images of resting (WT) and activated (CJD) microglia.

A

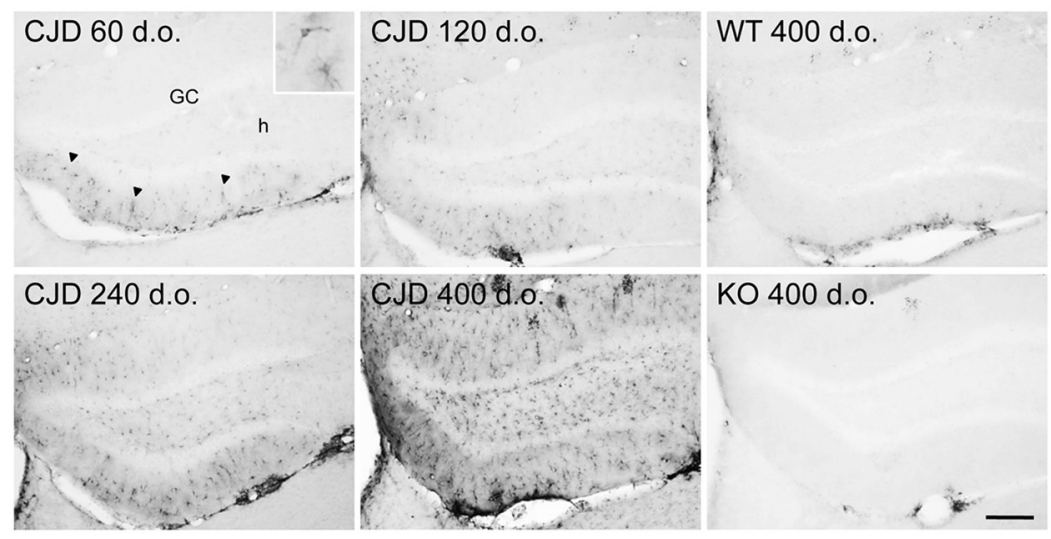

C

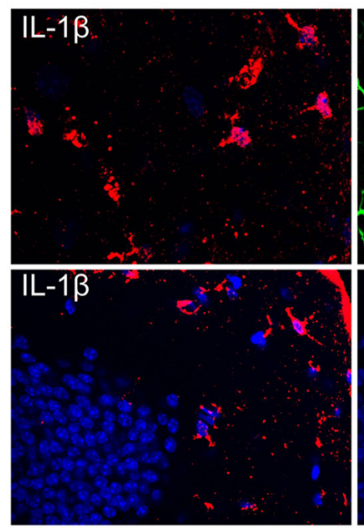

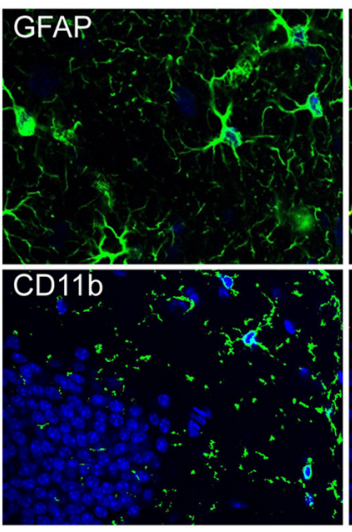

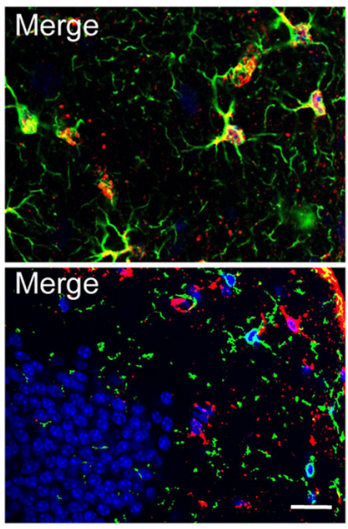

B

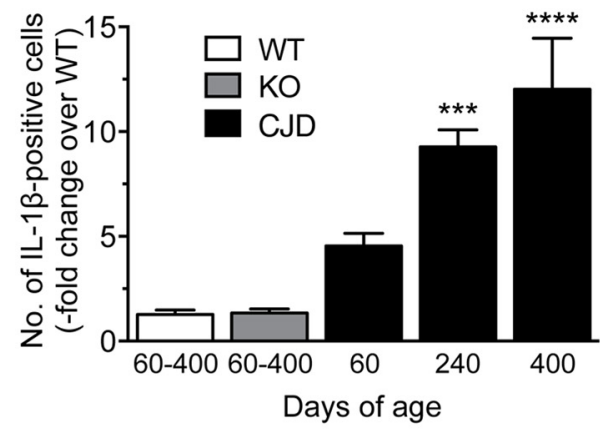

D

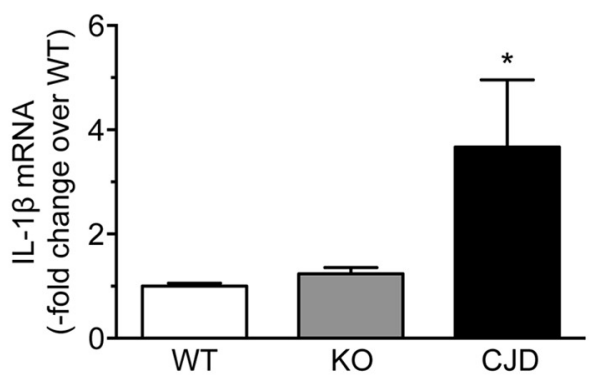

Figure 4. $\operatorname{Tg}(\mathrm{CD})$ mice have an age-related increase in IL-1 $\beta$-positive astrocytes in the hippocampus. $A$, Brain sections from the $\operatorname{Tg}(\mathrm{CJD}), \mathrm{WT}$, and PrP KO mice of the ages indicated were immunostained with anti-IL-1 $\beta$ antibody and nickel-intensified diaminobenzidine. Scale bar, $100 \mu \mathrm{m}$. Inset, High-magnification image of IL-1 $\beta$-positive cells. $\boldsymbol{B}$, The IL-1 $\beta$-immunopositive cells in the hippocampus of mice of different genotypes and ages were counted and expressed as the fold change over the numbers in WT mice. Data are the mean \pm SEM of $4-6$ animals ( $2-3$ brain sections each); $F_{(4,18)}=22.20, p<0.0001$ by one-way ANOVA; ***p $<0.001 ; * * * p<0.0001$ vs WT and KO by Tukey's post hoc test. C, Immunofluorescence staining of IL-1 $\beta$ (red) and GFAP or CD11b (green) in the dentate gyrus of the hippocampus of a $\mathrm{Tg}(\mathrm{CJD})$ mouse at $72 \mathrm{~d}$ of age. Sections were reacted with Hoechst 33258 to stain the cell nuclei (blue). The merged images show colocalization of IL-1 $\beta$ with GFAP, but not with CD11b. Scale bar, $10 \mu \mathrm{m}$. D. Total RNA was extracted from the hippocampi of 60- to 66-d-old WT, PrP K0, and Tg(CD) mice, and was analyzed by qRT-PCR for IL-1 $\beta$ and GAPDH. mRNAs were quantified by the $\Delta \Delta \mathrm{Ct}$ method and expressed as the fold increase over WT. Data are the mean \pm SEM of $4-5$ animals per group; $F_{(2,17)}=4.506, p=$ 0.0269 by one-way ANOVA; ${ }^{*} p<0.05$ vs WT and KO by Holm-Sidak post hoc test. 
A<smiles>C=CC(C)CC(C)C</smiles>

CJD

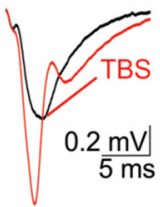

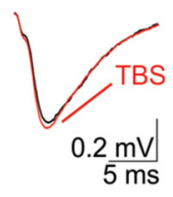

B

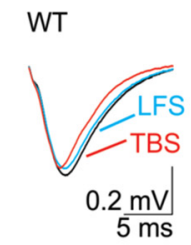

KO

CJD
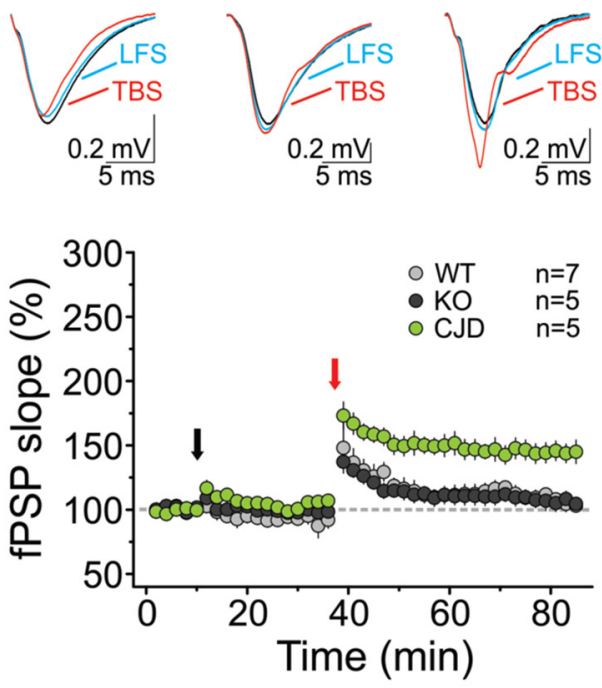

D
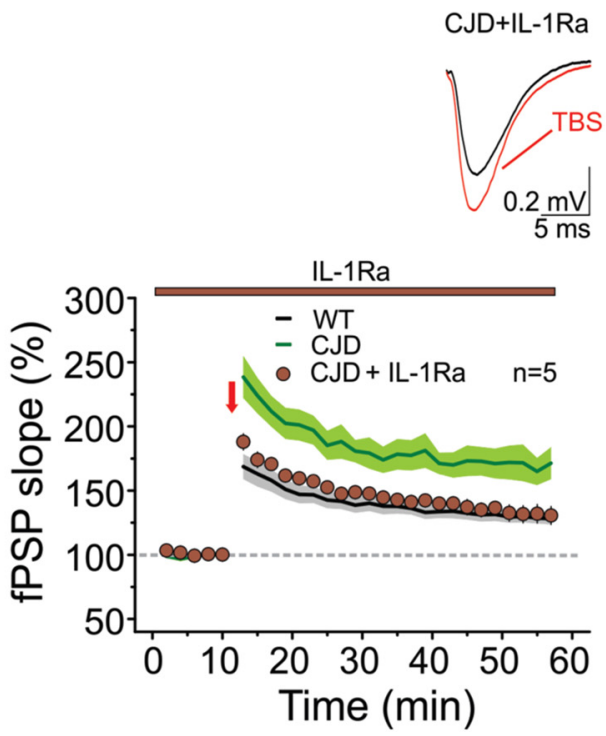

CJD+IL-1Ra

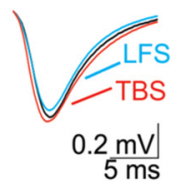

IL-1Ra

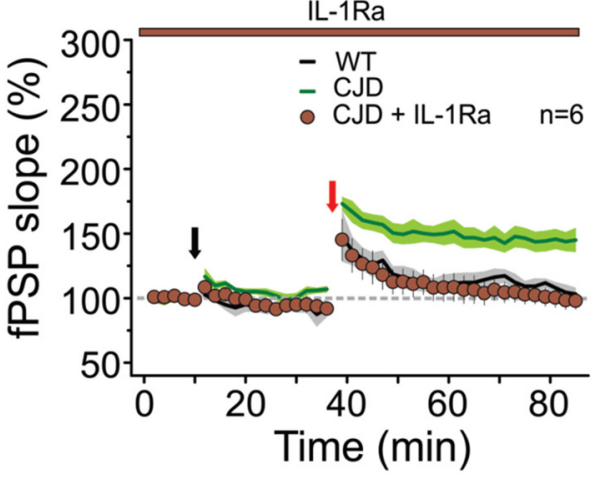

Figure 5. Aged $\operatorname{Tg}(\mathrm{CD})$ mice have altered hippocampal plasticity and metaplasticity, which are normalized by IL-1 receptor antagonism. $\boldsymbol{A}$, TBS induces LTP at the CA3-CA1 synapses of $\sim 300$-d-old WT mice (gray circles; RM1W, $F_{(9,9)}=36, p<0.0001$; Tukey's test, $p<0.01$ ). The same protocol fails to induce LTP in brain slices of age-matched PrP K0 mice (dark gray circles; RM1W, $\left.F_{(12,9)}=1.6, p=0.2\right)$. In slices from Tg(CJD) mice, TBS results in LTP (light green circles; RM1W, $F_{(4,9)}=31, p=0.003$; Tukey's test, $\left.p<0.05\right)$ larger than in controls (RM2W, $F_{(2,25)}=0.9, p=$ 0.6 ; WT vs K0, $p<0.05$; WT vs CJD, $p<0.001$; KO vs CJD, $p<0.001$; Tukey's post hoc test). Insets, Superimposed averaged records (5 traces) from WT (left), PrP K0 (center), and Tg (CJD) mice (right) before TBS (gray line) and 35-45 min after the TBS (red line). $B$, Upon LFS priming, LTP was absent in WT mice (gray circles; RM1W, $F_{(6,9)}=3, p=0.1$ ) and PrP K0 mice (dark gray circles; RM1W, $\left.F_{(4,9)}=1, p=0.4\right)$, but not in Tg(CJD) mice (light green circles; RM1W, $F_{(4,9)}=28, p=0.0024 ;$ Tukey's test, $p<0.01 ; \mathrm{RM} 2 \mathrm{~W}, F_{(2,14)}=0.6, p=0.7 ;$ WT vs K0, $p>0.05 ;$ WT vs CJD, $p<0.001$; KO vs CJD, $p<0.001$; Tukey's post hoc test). The priming stimulus did not significantly alter fPSP responses in Tg(CJD) mice compared with controls (WT mice: $92 \pm 5 \%$ of baseline, 7 mice, RM1W, $F_{(6,8)}=1.3, p=0.3 ; \operatorname{PrP}$ K0 mice: $98 \pm 5 \%$ of baseline, 5 mice, RM1W, $F_{(4,8)}=0.4, p=0.6 ; \mathrm{Tg}(\mathrm{CJD})$ mice: $104 \pm 3 \%$ of baseline, 5 mice, RM1W, $F_{(4,8)}=16, p=0.001 ;$ Tukey's test, $p>0.05$; $\mathrm{RM} 2 \mathrm{~W}, F_{(2,14)}=1.6, p=0.1$; WT vs K0,p>0.05; WT vs CJD, $p>0.05$; Tukey's post hoc test). Insets, Superimposed averaged records (5 traces) from WT (left), PrP K0 (center), and Tg(CJD) mice (right) before the priming stimulus (gray line), 15-25 min after the LFS (blue line), and 35-45 min after the TBS (red line). $\boldsymbol{A}, \boldsymbol{B}$, Averaged time courses (mean \pm SEM) of normalized fPSP slopes. TBS or LFS (in the metaplasticity experiments) was performed at the red and the black arrows, respectively. Dashed horizontal lines define baseline responses. C, Bath application of IL1-Ra reduced the magnitude of LTP in $\mathrm{Tg}(\mathrm{CJD})$ mice (brown circles; $\mathrm{RM1W}, F_{(4,9)}=22, p=0.0055$; Tukey's test, $p<0.05$; the green line from $A$ is reported here for comparison) to levels comparable to those of WT mice (black line, reported from $A$ for comparison; RM2W, $F_{(2,17)}=0.9, p=0.5$; (JD + IL-1Ra vs CJD, $p<0.05$; (JD + IL-1Ra vs WT, $p>0.05$; Tukey's post hoc test). Inset, Superimposed averaged records ( 5 traces) from CJD + IL-1Ra before the TBS (gray line) and 35- 45 min after the TBS (red line). D, Upon bath application of IL-1Ra, the LFS priming protocol prevented LTP in Tg(CJD) mice (brown circles; $\mathrm{RM} 1 \mathrm{~W}, F_{(5,9)}=0.2, p=0.7$; the green line from $\boldsymbol{B}$ is reported here for comparison), similar to WT controls (black line, reported from $\boldsymbol{B}$ for comparison; $\mathrm{RM} 2 \mathrm{~W}, F_{(2,15)}=1.5, p=$ 0.2 ; CJD + IL-1Ra vs CJD, $p<0.05$; (JD + IL-1Ra vs WT, $p>0.05$; Tukey's post hoc test). The priming stimulus did not significantly alter the fPSP responses in CJD mice (94 $\pm 6 \%$ of baseline, 6 mice, $\left.\mathrm{RM} 1 \mathrm{~W}, F_{(5,8)}=1.2, p=0.3\right)$ compared with controls $\left(\mathrm{RM} 2 \mathrm{~W}, F_{(2,15)}=0.9, p=0.6 ; \mathrm{CJD}+\mathrm{IL}-1\right.$ Ravs $\mathrm{CJD}, p>0.05 ; \mathrm{CJD}+\mathrm{IL}-1$ Ravs WT, $p>0.05 ;$ Tukey's posthoc test). Inset, Superimposed averaged records (5 traces) from CJD + IL-1Ra before the priming stimulus (gray line), 18-26 min after the LFS (blue line), and 35- 45 min after the TBS (red line). C, D, Averaged time courses (mean \pm SEM) of normalized fPSP amplitudes. TBS or LFS (in the metaplasticity experiments) was performed at the red and the black arrows, respectively. Dashed horizontal lines define baseline responses. 
A

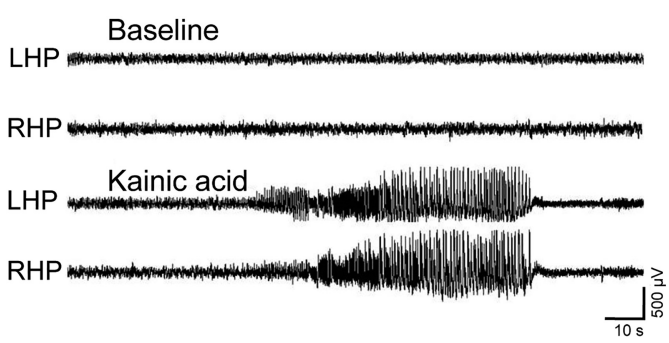

B

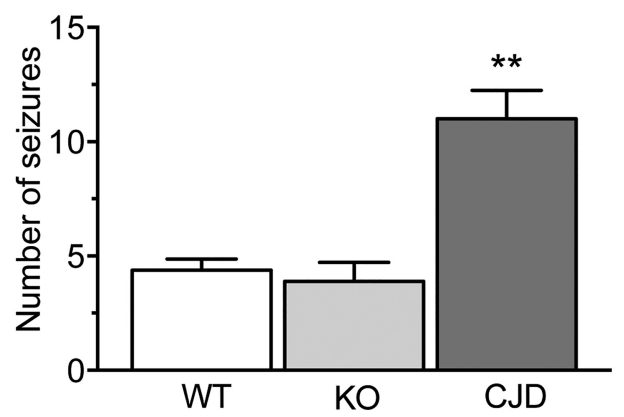

D

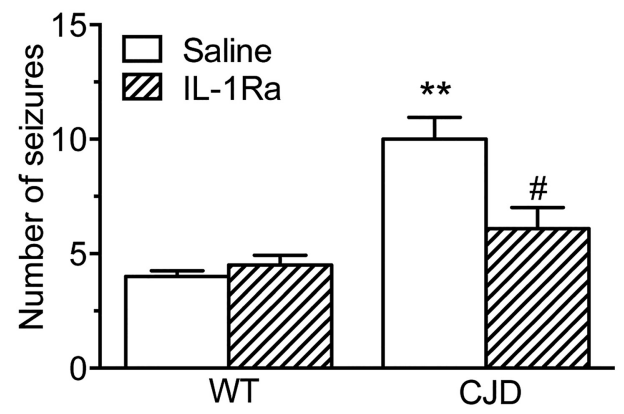

C

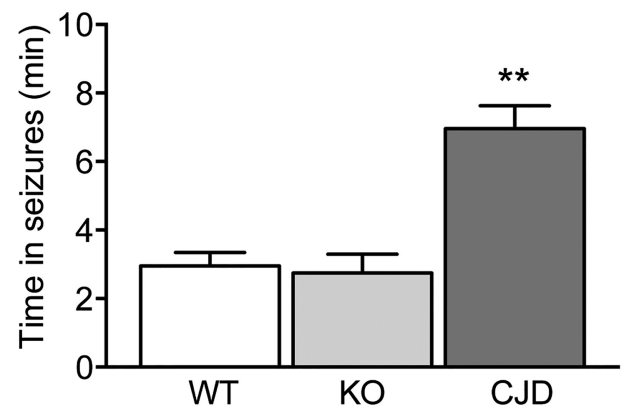

E

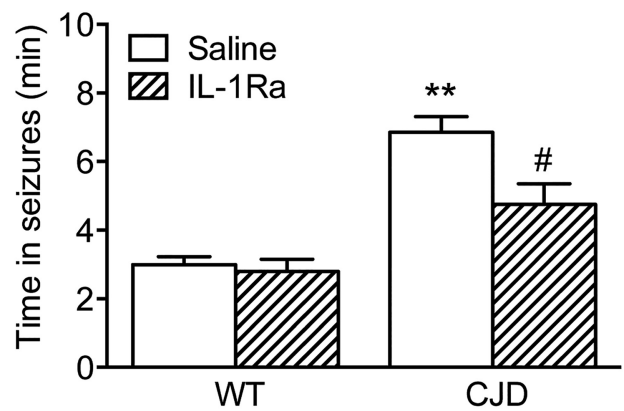

Figure 6. $\mathrm{Tg}(\mathrm{CJD})$ mice have increased susceptibility to kainate-induced seizures, which depends on IL-1 $\beta$ signaling. $\boldsymbol{A}$, Representative EEG tracings depicting baseline recordings (top) and ictal activity after intrahippocampal KA injection (bottom) in the left (LHP) and right (RHP) hippocampus in freely moving mice. B, C, Number of seizures and time spent in seizures in WT ( $n=8)$, PrP K0 $(n=9)$, and $\operatorname{Tg}(\mathrm{CJD})$ mice $(n=6)$ injected with KA. Data are the mean \pm SEM; $*{ }^{*} p<0.01$ vs WT and KO mice by one-way ANOVA $\left(F_{(2,20)}=19.41\right.$ in $B$ and $F_{(2,20)}=17.25$ in $\left.C, p<0.0001\right)$ followed by Tukey's test. $\boldsymbol{D}, \boldsymbol{E}$, Number of seizures and time spent in seizures in WT and $\mathrm{Tg}(\mathrm{CJD})$ mice injected with IL-1Ra (anakinra) or saline (intracerebroventricularly and bilaterally; $0.5 \mu \mathrm{g}$ in $0.5 \mu \mathrm{\mu l} / \mathrm{side}$ ), 10 min before KA. Data are the mean \pm SEM (9-10 each group); ${ }^{* *} p<0.01$ vs WT; and \#p $<0.05$ vs $\operatorname{Tg}(\mathrm{CD})+$ saline by Mann-Whitney test $(\boldsymbol{D} ; p=0.0102 ; \boldsymbol{E}, p=0.0133 ; \mathrm{Tg}(\mathrm{CJD})+\mathrm{IL}-1 \mathrm{Ra}$ vs $\operatorname{Tg}(\mathrm{CJD}))$.

animals $(107 \pm 5 \%$ of baseline; 7 mice; $p>0.05)$ but failed to abolish it in $\operatorname{Tg}(\mathrm{CJD})$ mice ( $145 \pm 8 \% ; 5$ mice; $p<0.01$; Fig. $5 B)$, similar to what was seen at $\sim 100 \mathrm{~d}$. In $\sim 300$-d-old PrP KO mice, we could not detect any metaplastic phenomena (107 $\pm 6 \% ; 5$ mice; $p>0.05$ ), due to impaired LTP even in the absence of LFS (Fig. $5 B$ ). As in $\sim 100$-d-old animals, the priming protocol did not modify the basal synaptic responses per se (Fig. $5 B$ ).

Next, we tested whether blocking IL- $1 \beta$ signaling could correct the abnormal plasticity in $\mathrm{Tg}(\mathrm{CJD})$ mice. Bath application of anakinra, the human recombinant IL-1 receptor type 1 antagonist (IL-1Ra), on brain slices from $\operatorname{Tg}(\mathrm{CJD})$ mice reduced the LTP to a level comparable to that of WT controls (133 $\pm 6 \%$ of baseline; 5 mice; $p<0.05$; Fig. $5 C$ ). IL- 1 Ra also normalized metaplasticity in the mutant mice $(100 \pm 7 \%$; 6 mice; $p>0.05)$, restoring the effectiveness of the priming protocol in preventing the induction of LTP (Fig. 5D).

These results indicate that IL- $1 \beta$ contributes to the metaplastic abnormalities and the age-dependent increase in hippocampal synaptic responsiveness in $\operatorname{Tg}(\mathrm{CJD})$ mice.
$\operatorname{Tg}(\mathrm{CJD})$ mice have enhanced susceptibility to kainate-induced seizures, which depends on IL-1 $\beta$ signaling

Since IL- $1 \beta$, by promoting SFK activation and GluN2B phosphorylation (Viviani et al., 2003), has proconvulsive effects (Balosso et al., 2008; Galic et al., 2008), we tested whether the $\mathrm{Tg}(\mathrm{CJD})$ mice were more prone to seizures. Focal-onset acute seizures were induced by unilateral intrahippocampal injection of $\mathrm{KA}$ in $\mathrm{Tg}(\mathrm{CJD}), \mathrm{PrP} \mathrm{KO}$, and WT mice between the ages of 210 and $310 \mathrm{~d}$. EEG recordings showed there were more seizures and longer times in ictal activity in $\mathrm{Tg}(\mathrm{CJD})$ mice than in PrP KO and WT mice (Fig. $6 A-C$ ). To test the contribution of IL- $1 \beta$ signaling in this seizure susceptibility, we injected $\operatorname{Tg}(\mathrm{CJD})$ mice with IL$1 \mathrm{Ra}(0.5 \mu \mathrm{g}$ in $0.5 \mu$ l, i.c.v. $) 10 \mathrm{~min}$ before intrahippocampal KA. The number of seizures and time in ictal activity were significantly reduced in $\mathrm{Tg}(\mathrm{CJD})$ mice but not in WT mice (Fig. 6D,E).

To exclude that differences in rearing conditions between commercial WT mice and $\mathrm{Tg}(\mathrm{CJD})$ and PrP KO mice raised inhouse could affect the results, we compared the susceptibility to kainate-induced seizures of C57BL/6J adult male mice purchased 
from our external provider and exposed to seizures 2 weeks after arrival in our animal facility to that of mice of the same strain, age, and sex that were born and raised in-house ( 7 mice/group). We found no significant differences in time to seizure onset, number of seizures, and time in seizure between the two groups (mean \pm $\mathrm{SD}$; WT raised in-house: $10.0 \pm 4.0 \mathrm{~min}, 7.9 \pm 2.3,6.7 \pm 2.3 \mathrm{~min}$; WT from Envigo: $8.0 \pm 2.6 \mathrm{~min}, 6.9 \pm 3.7,5.0 \pm 1.8 \mathrm{~min}$ ).

\section{Discussion}

The present study found that $\operatorname{Tg}(\mathrm{CJD})$ mice, which express a misfolded mutant PrP, had alterations in hippocampal metaplasticity and an age-related increase in the magnitude of LTP. They also had high levels of phosphorylated GluN2B, indicative of enhanced NMDAR activity, and were intrinsically more susceptible to hippocampal seizures. Subtle alterations in synaptic metaplasticity and a modest increase in GluN2B phosphorylation were also seen in PrP KO mice. However, these mice had an agedependent decrease in LTP, and no alterations in hippocampal seizure susceptibility. $\operatorname{Tg}(\mathrm{CJD})$ mice had proinflammatory changes, with progressive astrogliosis and microgliosis, and more IL- $1 \beta$ positive astrocytes in the hippocampus. Blocking IL- $1 \beta$ signaling rescued the abnormalities in metaplasticity and the age-related increase in LTP, and significantly reduced susceptibility to seizures.

These findings indicate an enhancement of NMDA-dependent synaptic signaling in the $\operatorname{Tg}(\mathrm{CJD})$ hippocampus, which may result from a combination of the loss and gain of function of mutant PrP and involves neuroinflammation. They suggest that anti-inflammatory drugs that block IL- $1 \beta$ signaling, perhaps in combination with NMDAR antagonists, may help to normalize hippocampal synaptic activity, with beneficial effects on the symptomatic expression of disease.

\section{$\mathrm{Tg}(\mathrm{CJD})$ and PrP KO mice develop similar and divergent abnormalities in hippocampal synaptic plasticity}

In hippocampal slices from $\sim 100$-d-old $\mathrm{Tg}(\mathrm{CJD})$ mice, LTP was normal at the CA3-CA1 synapses, but there was an inversion of metaplasticity, with a significant increase in phosphorylation of the NMDAR GluN2B subunit at tyrosine residue 1472. Phosphorylation at this $\mathrm{C}$-terminal regulatory site prevents endocytosis of GluN2B, enhancing its cell surface expression and NMDAR activity (Salter and Kalia, 2004). In the hippocampus, low-frequency $(10 \mathrm{~Hz})$ presynaptic stimulation triggers NMDA-dependent metaplastic changes that inhibit the induction of LTP (Zhang et al., 2005). This homeostatic control may serve to prevent LTP from occurring too readily in response to weak stimuli or to restrain LTP induction after strong stimuli, thus helping to maintain synaptic efficacy within a dynamic range permissive for a learning-ready state and memory retention (Abraham, 2008). The GluN2B-type NMDARs mediate maximal increases in intracellular $\mathrm{Ca}^{2+}$ in response to low-frequency stimulation, while GluN2A-type receptors activate maximally in response to highfrequency synaptic inputs (Erreger et al., 2005). The hyperphosphorylation of GluN2B in $\mathrm{Tg}(\mathrm{CJD})$ mice may change the biophysical properties of NMDAR, with consequent alterations in postsynaptic $\mathrm{Ca}^{2+}$ dynamic and downstream $\mathrm{Ca}^{2+}$-dependent signaling after the $10 \mathrm{~Hz}$ priming stimulus. This may lead to the inversion of metaplasticity without affecting LTP and potentially contribute to the memory impairment that develops in these mice (Dossena et al., 2008).

There was a modest increase in phospho-Tyr1472 GluN2B in $\mathrm{PrP}$ KO mice. There is evidence that PrP participates in a signaling cascade that activates SFK Fyn and promotes GluN2B phosphorylation (Um et al., 2012), and the loss of PrP may result in constitutive activation of this signaling. We have also found that
PrP interacts physically with GluN2B (unpublished observation), possibly promoting its intracellular transport, or acting as a scaffold protein to target the receptor to specific microdomains of the synaptic membrane (Senatore et al., 2013). GluN2B may be hyperphosphorylated in $\mathrm{PrP} \mathrm{KO}$ mice as an adaptive response to permit interaction with other proteins that favor its cell surface expression (Maier et al., 2013). The modest increase of phosphoTyr1472 GluN2B in the hippocampus of PrP KO mice, however, does not appear to have important functional consequences, since metaplasticity is only slightly altered, and mice are not impaired in hippocampus-dependent learning and memory (Dossena et al., 2008; Bouybayoune et al., 2015; unpublished data). Other mechanisms should therefore presumably be operative in $\mathrm{Tg}(\mathrm{CJD})$ mice that raise GluN2B phosphorylation over the level induced by the loss of $\operatorname{PrP}$, leading to hippocampal dysfunction.

We previously reported that PrP deposition in the brains of $\operatorname{Tg}(\mathrm{CJD})$ mice was associated with prominent hypertrophy and proliferation of astrocytes in the hippocampus (Dossena et al., 2008). We have now shown that microglia are also activated, and that both microgliosis and astrogliosis prefigure the appearance of neurological deficits and increase further during the symptomatic phase of the disease, most likely reflecting the progressive accumulation of misfolded PrP (Bouybayoune et al., 2015). The novel information is that hippocampal IL- $1 \beta$ is specifically raised in astrocytes, in accordance with previous evidence of high wholetissue levels in variant and sporadic CJD and in CJD-infected mice (Kordek et al., 1996; Sharief et al., 1999; Shi et al., 2013; Llorens et al., 2014).

The mechanism by which misfolded mutant PrP triggers IL- $1 \beta$ biosynthesis in astroglial cells in vivo is not known. The application of the neurotoxic PrP106-126 peptide to cultured astrocytes and microglial cells stimulates their proliferation and IL- $1 \beta$ release through the activation of nuclear factor- $\kappa \mathrm{B}$ (Forloni et al., 1994; Hafiz and Brown, 2000; Lu et al., 2012), suggesting that the misfolded PrP in the brains of $\operatorname{Tg}(\mathrm{CJD})$ mice may have a similar effect.

Electrophysiological analysis detected a dramatic increase in hippocampal LTP magnitude in 300-d-old Tg(CJD) mice and weakened LTP in PrP KO littermates, clearly differentiating the effects of mutant PrP from those of PrP deletion. At this age, we saw a marked increase of IL- $1 \beta$-positive astrocytes in the Tg(CJD) hippocampus. IL- $1 \beta$ dose-dependently induced GluN2B phosphorylation in cultured hippocampal neurons through the activation of SFK, and this effect was abolished by the IL-1 receptor antagonist (Viviani et al., 2003). Consistent with a role of IL-1 $\beta$ in altering NMDAR responses in $\mathrm{Tg}(\mathrm{CJD})$ mice, IL-1Ra restored normal LTP and rescued the metaplastic defect in brain slices.

Hypersynchronous hippocampal bursting caused by enhanced NMDAR-mediated excitation has been reported in mice infected with vCJD prions (Ratté et al., 2008). In the light of the high IL-1 $\beta$ levels in vCJD patients (Sharief et al., 1999), it may be worth measuring this cytokine in the brain of vCJD-infected mice and test whether anakinra prevents these hypersynchronous hippocampal bursting.

LTP was significantly impaired in $\sim 300$-d-old PrP KO mice. An age-related alteration in hippocampal LTP was previously reported in Zürich I PrP KO mice (the strain also used in our study) and in an independently generated line of coisogenic 129/ Ola mice in which the Prnp locus was disrupted using a different strategy (Curtis et al., 2003). However, analysis of hippocampal synaptic plasticity in $\mathrm{PrP} \mathrm{KO}$ mice has produced conflicting results (Collinge et al., 1994; Manson et al., 1995; Lledo et al., 1996; Maglio et al., 2004, 2006). Differences in the induction protocol, 
animal model, and/or age of the mice may account for these. Zürich I mice, as well as mice in which PrP was postnatally ablated only in neurons, also had a significant attenuation of afterhyperpolarization potentials in CA1 pyramidal neurons (Colling et al., 1996; Mallucci et al., 2002), supporting a direct role for PrP in hippocampal excitability.

\section{Tg(CJD) but not PrP KO mice show enhanced susceptibility} to hippocampal seizures, which depends on IL-1 $\beta$ signaling $\mathrm{Tg}(\mathrm{CJD})$ mice were intrinsically more susceptible to hippocampal seizures, suggesting a low seizure threshold. The competitive IL-1R type 1 antagonist IL-1Ra significantly blocked this effect, indicating that it was mediated by the endogenous IL- $1 \beta$, which was increased in $\operatorname{Tg}(\mathrm{CJD})$ mouse hippocampus. In full accordance with this, there is evidence that intrahippocampally injected IL- $1 \beta$ increases kainate seizures - and other types of seizures_in rodents (Vezzani et al., 1999, 2000; Maroso et al., 2011; Iori et al., 2017), and IL- $1 \beta$ proictogenic effects were blocked by IL-1Ra (Vezzani et al., 1999, 2000). Gliosis was attenuated, disease onset was delayed, and survival was significantly prolonged in prion-infected mice lacking IL-1R type 1 (Schultz et al., 2004; Tamgüney et al., 2008). The effects of IL- $1 \beta$ on seizures are mediated by Src family kinase phosphorylation of GluN2B, which promotes neuronal $\mathrm{Ca}^{2+}$ influx (Viviani et al., 2003; Balosso et al., 2008). Since IL-1 $\beta$ is increased in the brain and CSF of CJD patients, this may contribute to the synaptic alterations and seizures in patients in advanced stages of the disease (Wieser et al., 2006). These data support the idea that anakinra, or other anti-IL-1 $\beta$ drugs, might have therapeutic effects in prion diseases. Notably, two proof-of-concept clinical studies have recently shown that anakinra is effective in treating drug-resistant seizures in epilepsy patients (Jyonouchi and Geng, 2016; Kenney-Jung et al., 2016).

At variance with previous observations (Walz et al., 1999; Rangel et al., 2007), we found no difference in susceptibility to seizures between PrP KO and WT mice; this might be due to focal rather than systemic administration of KA, the latter also involving extrahippocampal brain regions contributing to seizures. In addition, we used mice with a homogeneous C57BL/6J background, whereas other studies used PrP KO mice with mixed genetic backgrounds (typically $129 \mathrm{~Sv} \times \mathrm{C} 57 \mathrm{BL} / 6 \mathrm{~J}$ ), and genetic heterogeneity may profoundly affect seizure susceptibility in mice (Schauwecker, 2011; Striebel et al., 2013a,b).

Animal husbandry and rearing conditions can also affect susceptibility to seizures (Leussis and Heinrichs, 2006, 2009), and our C57BL/6J controls were purchased from an external provider whereas the $\operatorname{Tg}(\mathrm{CJD})$ and $\mathrm{PrP} \mathrm{KO}$ mice were raised in-house. However, this difference is unlikely to have affected our results since we found no differences in seizure susceptibility between C57BL/6J mice purchased from Envigo and those that were born and raised in-house. Moreover, all mice from the external vendor were housed for at least 2 weeks in our animal facilities together with $\mathrm{Tg}(\mathrm{CJD})$ and PrP KO mice before being used for the experiments.

In summary, we provide evidence of dysfunctional NMDAdependent hippocampal synaptic plasticity and enhanced seizure susceptibility in $\operatorname{Tg}(\mathrm{CJD})$ mice. These effects appear to result from altered NMDAR activity and neuroinflammation. Targeting NMDAR and IL- $1 \beta$ signaling with clinically available drugs may be beneficial in the symptomatic treatment of the disease.

\section{References}

Abraham WC (2008) Metaplasticity: tuning synapses and networks for plasticity. Nat Rev Neurosci 9:387. CrossRef Medline

Balducci C, Tonini R, Zianni E, Nazzaro C, Fiordaliso F, Salio M, Vismara L,
Gardoni F, Di Luca M, Carli M, Forloni G (2010) Cognitive deficits associated with alteration of synaptic metaplasticity precede plaque deposition in AbetaPP23 transgenic mice. J Alzheimers Dis 21:1367-1381. CrossRef Medline

Balosso S, Maroso M, Sanchez-Alavez M, Ravizza T, Frasca A, Bartfai T, Vezzani A (2008) A novel non-transcriptional pathway mediates the proconvulsive effects of interleukin-1beta. Brain 131:3256-3265. CrossRef Medline

Blitzer RD, Connor JH, Brown GP, Wong T, Shenolikar S, Iyengar R, Landau EM (1998) Gating of CaMKII by cAMP-regulated protein phosphatase activity during LTP. Science 280:1940-1942. CrossRef Medline

Bouybayoune I, Mantovani S, Del Gallo F, Bertani I, Restelli E, Comerio L, Tapella L, Baracchi F, Fernández-Borges N, Mangieri M, Bisighini C, Beznoussenko GV, Paladini A, Balducci C, Micotti E, Forloni G, Castilla J, Fiordaliso F, Tagliavini F, Imeri L, et al (2015) Transgenic fatal familial insomnia mice indicate prion infectivity-independent mechanisms of pathogenesis and phenotypic expression of disease. PLoS Pathog 11: e1004796. CrossRef Medline

Brown DR, Herms JW, Schmidt B, Kretzschmar HA (1997) Prp and betaamyloid fragments activate different neurotoxic mechanisms in cultured mouse cells. Eur J Neurosci 9:1162-1169. CrossRef Medline

Büeler H, Fischer M, Lang Y, Bluethmann H, Lipp HP, DeArmond SJ, Prusiner SB, Aguet M, Weissmann C (1992) Normal development and behaviour of mice lacking the neuronal cell-surface PrP protein. Nature 356:577-582. CrossRef Medline

Carulla P, Llorens F, Matamoros-Angles A, Aguilar-Calvo P, Espinosa JC, Gavín R, Ferrer I, Legname G, Torres JM, del Río JA (2015) Involvement of $\operatorname{Pr} \mathrm{P}(\mathrm{C})$ in kainate-induced excitotoxicity in several mouse strains. Sci Rep 5:11971. CrossRef Medline

Chiesa R (2015) The elusive role of the prion protein and the mechanism of toxicity in prion disease. PLoS Pathog 11:e1004745. CrossRef Medline

Christie BR, Stellwagen D, Abraham WC (1995) Reduction of the threshold for long-term potentiation by prior theta-frequency synaptic activity. Hippocampus 5:52-59. CrossRef Medline

Colby DW, Prusiner SB (2011) Prions. Cold Spring Harb Perspect Biol 3:a006833. CrossRef Medline

Colling SB, Collinge J, Jefferys JG (1996) Hippocampal slices from prion protein null mice: disrupted $\mathrm{Ca}(2+)$-activated $\mathrm{K}+$ currents. Neurosci Lett 209:49-52. CrossRef Medline

Collinge J, Whittington MA, Sidle KC, Smith CJ, Palmer MS, Clarke AR, Jefferys JG (1994) Prion protein is necessary for normal synaptic function. Nature 370:295-297. CrossRef Medline

Costello DA, Watson MB, Cowley TR, Murphy N, Murphy Royal C, Garlanda C, Lynch MA (2011) Interleukin- $1 \alpha$ and HMGB1 mediate hippocampal dysfunction in SIGIRR-deficient mice. J Neurosci 31:3871-3879. CrossRef Medline

Costello DA, Claret M, Al-Qassab H, Plattner F, Irvine EE, Choudhury AI, Giese KP, Withers DJ, Pedarzani P (2012) Brain deletion of insulin receptor substrate 2 disrupts hippocampal synaptic plasticity and metaplasticity. PLoS One 7:e31124. CrossRef Medline

Curtis J, Errington M, Bliss T, Voss K, MacLeod N (2003) Age-dependent loss of PTP and LTP in the hippocampus of PrP-null mice. Neurobiol Dis 13:55-62. CrossRef Medline

De Simoni MG, Perego C, Ravizza T, Moneta D, Conti M, Marchesi F, De Luigi A, Garattini S, Vezzani A (2000) Inflammatory cytokines and related genes are induced in the rat hippocampus by limbic status epilepticus. Eur J Neurosci 12:2623-2633. CrossRef Medline

Dossena S, Imeri L, Mangieri M, Garofoli A, Ferrari L, Senatore A, Restelli E, Balducci C, Fiordaliso F, Salio M, Bianchi S, Fioriti L, Morbin M, Pincherle A, Marcon G, Villani F, Carli M, Tagliavini F, Forloni G, Chiesa R (2008) Mutant prion protein expression causes motor and memory deficits and abnormal sleep patterns in a transgenic mouse model. Neuron 60:598-609. CrossRef Medline

Erreger K, Dravid SM, Banke TG, Wyllie DJ, Traynelis SF (2005) Subunitspecific gating controls rat NR1/NR2A and NR1/NR2B NMDA channel kinetics and synaptic signalling profiles. J Physiol 563:345-358. CrossRef Medline

Espinosa PS, Bensalem-Owen MK, Fee DB (2010) Sporadic CreutzfeldtJakob disease presenting as nonconvulsive status epilepticus case report and review of the literature. Clin Neurol Neurosurg 112:537-540. CrossRef Medline

Forloni G, Del Bo R, Angeretti N, Chiesa R, Smiroldo S, Doni R, Ghibaudi E, 
Salmona M, Porro M, Verga L (1994) A neurotoxic prion protein fragment induces rat astroglial proliferation and hypertrophy. Eur J Neurosci 6:1415-1422. CrossRef Medline

Galic MA, Riazi K, Heida JG, Mouihate A, Fournier NM, Spencer SJ, Kalynchuk LE, Teskey GC, Pittman QJ (2008) Postnatal inflammation increases seizure susceptibility in adult rats. J Neurosci 28:6904-6913. CrossRef Medline

Gisabella B, Rowan MJ, Anwyl R (2003) Mechanisms underlying the inhibition of long-term potentiation by preconditioning stimulation in the hippocampus in vitro. Neuroscience 121:297-305. CrossRef Medline

Hafiz FB, Brown DR (2000) A model for the mechanism of astrogliosis in prion disease. Mol Cell Neurosci 16:221-232. CrossRef Medline

Head MW, Ironside JW (2012) Review: Creutzfeldt-Jakob disease: prion protein type, disease phenotype and agent strain. Neuropathol Appl Neurobiol 38:296-310. CrossRef Medline

Huang Y, Lu W, Ali DW, Pelkey KA, Pitcher GM, Lu YM, Aoto H, Roder JC, Sasaki T, Salter MW, MacDonald JF (2001) CAKbeta/Pyk2 kinase is a signaling link for induction of long-term potentiation in CA1 hippocampus. Neuron 29:485-496. CrossRef Medline

Hulme SR, Jones OD, Abraham WC (2013) Emerging roles of metaplasticity in behaviour and disease. Trends Neurosci 36:353-362. CrossRef Medline

Iori V, Maroso M, Rizzi M, Iyer AM, Vertemara R, Carli M, Agresti A, Antonelli A, Bianchi ME, Aronica E, Ravizza T, Vezzani A (2013) Receptor for Advanced Glycation Endproducts is upregulated in temporal lobe epilepsy and contributes to experimental seizures. Neurobiol Dis 58:102114. CrossRef Medline

Iori V, Iyer AM, Ravizza T, Beltrame L, Paracchini L, Marchini S, Cerovic M, Hill C, Ferrari M, Zucchetti M, Molteni M, Rossetti C, Brambilla R, Steve White H, D'Incalci M, Aronica E, Vezzani A (2017) Blockade of the IL-1R1/TLR4 pathway mediates disease-modification therapeutic effects in a model of acquired epilepsy. Neurobiol Dis 99:12-23. CrossRef Medline

Jyonouchi H, Geng L (2016) Intractable epilepsy (IE) and responses to anakinra, a human recombinant IL-1 receptor agonist (IL-1ra): case reports. J Clin Cell Immunol 7:5. CrossRef

Kenney-Jung DL, Vezzani A, Kahoud RJ, LaFrance-Corey RG, Ho ML, Muskardin TW, Wirrell EC, Howe CL, Payne ET (2016) Febrile infectionrelated epilepsy syndrome treated with anakinra. Ann Neurol 80:939945. CrossRef

Khosravani H, Zhang Y, Tsutsui S, Hameed S, Altier C, Hamid J, Chen L, Villemaire M, Ali Z, Jirik FR, Zamponi GW (2008) Prion protein attenuates excitotoxicity by inhibiting NMDA receptors. J Cell Biol 181:551565. CrossRef Medline

Kilkenny C, Browne WJ, Cuthill IC, Emerson M, Altman DG (2010) Improving bioscience research reporting: the ARRIVE guidelines for reporting animal research. PLoS Biol 8:e1000412. CrossRef Medline

Kordek R, Nerurkar VR, Liberski PP, Isaacson S, Yanagihara R, Gajdusek DC (1996) Heightened expression of tumor necrosis factor alpha, interleukin 1 alpha, and glial fibrillary acidic protein in experimental CreutzfeldtJakob disease in mice. Proc Natl Acad Sci U S A 93:9754-9758. CrossRef Medline

Leussis MP, Heinrichs SC (2006) Routine tail suspension husbandry facilitates onset of seizure susceptibility in EL mice. Epilepsia 47:801-804. CrossRef Medline

Leussis MP, Heinrichs SC (2009) Quality of rearing guides expression of behavioral and neural seizure phenotypes in EL mice. Brain Res 1260:8493. CrossRef Medline

Lledo PM, Tremblay P, DeArmond SJ, Prusiner SB, Nicoll RA (1996) Mice deficient for prion protein exhibit normal neuronal excitability and synaptic transmission in the hippocampus. Proc Natl Acad Sci U S A 93: 2403-2407. CrossRef Medline

Llorens F, López-González I, Thüne K, Carmona M, Zafar S, Andréoletti O, Zerr I, Ferrer I (2014) Subtype and regional-specific neuroinflammation in sporadic Creutzfeldt-Jakob disease. Front Aging Neurosci 6:198. CrossRef Medline

Lu YM, Roder JC, Davidow J, Salter MW (1998) Src activation in the induction of long-term potentiation in CA1 hippocampal neurons. Science 279:1363-1367. CrossRef Medline

Lu Y, Liu A, Zhou X, Kouadir M, Zhao W, Zhang S, Yin X, Yang L, Zhao D (2012) Prion peptide PrP106-126 induces inducible nitric oxide synthase and proinflammatory cytokine gene expression through the activa- tion of NF-kappaB in macrophage cells. DNA Cell Biol 31:833-838. CrossRef Medline

MacDonald JF, Jackson MF, Beazely MA (2006) Hippocampal long-term synaptic plasticity and signal amplification of NMDA receptors. Crit Rev Neurobiol 18:71-84. CrossRef Medline

Maglio LE, Perez MF, Martins VR, Brentani RR, Ramirez OA (2004) Hippocampal synaptic plasticity in mice devoid of cellular prion protein. Brain Res Mol Brain Res 131:58-64. CrossRef Medline

Maglio LE, Martins VR, Izquierdo I, Ramirez OA (2006) Role of cellular prion protein on LTP expression in aged mice. Brain Res 1097:11-18. CrossRef Medline

Maier W, Bednorz M, Meister S, Roebroek A, Weggen S, Schmitt U, Pietrzik CU (2013) LRP1 is critical for the surface distribution and internalization of the NR2B NMDA receptor subtype. Mol Neurodegener 8:25. CrossRef Medline

Mallucci GR, Ratté S, Asante EA, Linehan J, Gowland I, Jefferys JG, Collinge J (2002) Post-natal knockout of prion protein alters hippocampal CA1 properties, but does not result in neurodegeneration. EMBO J 21:202210. CrossRef Medline

Manson JC, Hope J, Clarke AR, Johnston A, Black C, MacLeod N (1995) PrP gene dosage and long term potentiation. Neurodegeneration 4:113-114. CrossRef Medline

Maroso M, Balosso S, Ravizza T, Iori V, Wright CI, French J, Vezzani A (2011) Interleukin-1beta biosynthesis inhibition reduces acute seizures and drug resistant chronic epileptic activity in mice. Neurotherapeutics 8:304-315. CrossRef Medline

Mejías-Aponte CA, Jiménez-Rivera CA, Segarra AC (2002) Sex differences in models of temporal lobe epilepsy: role of testosterone. Brain Res 944: 210-218. CrossRef Medline

Müller WE, Ushijima H, Schröder HC, Forrest JM, Schatton WF, Rytik PG, Heffner-Lauc M (1993) Cytoprotective effect of NMDA receptor antagonists on prion protein (PrionSc)-induced toxicity in rat cortical cell cultures. Eur J Pharmacol 246:261-267. CrossRef Medline

Nazzaro C, Greco B, Cerovic M, Baxter P, Rubino T, Trusel M, Parolaro D, Tkatch T, Benfenati F, Pedarzani P, Tonini R (2012) SK channel modulation rescues striatal plasticity and control over habit in cannabinoid tolerance. Nat Neurosci 15:284-293. CrossRef Medline

Perovic S, Pergande G, Ushijima H, Kelve M, Forrest J, Müller WE (1995) Flupirtine partially prevents neuronal injury induced by prion protein fragment and lead acetate. Neurodegeneration 4:369-374. CrossRef Medline

Puoti G, Bizzi A, Forloni G, Safar JG, Tagliavini F, Gambetti P (2012) Sporadic human prion diseases: molecular insights and diagnosis. Lancet Neurol 11:618-628. CrossRef Medline

Rangel A, Burgaya F, Gavín R, Soriano E, Aguzzi A, Del Río JA (2007) Enhanced susceptibility of Prnp-deficient mice to kainate-induced seizures, neuronal apoptosis, and death: role of AMPA/kainate receptors. J Neurosci Res 85:2741-2755. CrossRef Medline

Rangel A, Madroñal N, Gruart i Massó A, Gavín R, Llorens F, Sumoy L, Torres JM, Delgado-García JM, Del Río JA (2009) Regulation of GABA(A) and glutamate receptor expression, synaptic facilitation and long-term potentiation in the hippocampus of prion mutant mice. PLoS One 4:e7592. CrossRef Medline

Ratté S, Prescott SA, Collinge J, Jefferys JG (2008) Hippocampal bursts caused by changes in NMDA receptor-dependent excitation in a mouse model of variant CJD. Neurobiol Dis 32:96-104. CrossRef Medline

Resenberger UK, Harmeier A, Woerner AC, Goodman JL, Müller V, Krishnan R, Vabulas RM, Kretzschmar HA, Lindquist S, Hartl FU, Multhaup G, Winklhofer KF, Tatzelt J (2011) The cellular prion protein mediates neurotoxic signalling of beta-sheet-rich conformers independent of prion replication. EMBO J 30:2057-2070. CrossRef Medline

Ross FM, Allan SM, Rothwell NJ, Verkhratsky A (2003) A dual role for interleukin-1 in LTP in mouse hippocampal slices. J Neuroimmunol 144: 61-67. CrossRef Medline

Salter MW, Kalia LV (2004) Src kinases: a hub for NMDA receptor regulation. Nat Rev Neurosci 5:317-328. CrossRef Medline

Schauwecker PE (2011) The relevance of individual genetic background and its role in animal models of epilepsy. Epilepsy Res 97:1-11. CrossRef Medline

Schultz J, Schwarz A, Neidhold S, Burwinkel M, Riemer C, Simon D, Kopf M, Otto M, Baier M (2004) Role of interleukin-1 in prion disease-associated astrocyte activation. Am J Pathol 165:671-678. CrossRef Medline 
Senatore A, Colleoni S, Verderio C, Restelli E, Morini R, Condliffe SB, Bertani I, Mantovani S, Canovi M, Micotti E, Forloni G, Dolphin AC, Matteoli M, Gobbi M, Chiesa R (2012) Mutant PrP suppresses glutamatergic neurotransmission in cerebellar granule neurons by impairing membrane delivery of VGCC alpha(2)delta-1 subunit. Neuron 74:300-313. CrossRef Medline

Senatore A, Restelli E, Chiesa R (2013) Synaptic dysfunction in prion diseases: a trafficking problem? Int J Cell Biol 2013:543803. CrossRef Medline

Sharief MK, Green A, Dick JP, Gawler J, Thompson EJ (1999) Heightened intrathecal release of proinflammatory cytokines in Creutzfeldt-Jakob disease. Neurology 52:1289-1291. CrossRef Medline

Shi Q, Xie WL, Zhang B, Chen LN, Xu Y, Wang K, Ren K, Zhang XM, Chen C, Zhang J, Dong XP (2013) Brain microglia were activated in sporadic CJD but almost unchanged in fatal familial insomnia and G114V genetic CJD. Virol J 10:216. CrossRef Medline

Sikorska B, Knight R, Ironside JW, Liberski PP (2012) Creutzfeldt-Jakob disease. Adv Exp Med Biol 724:76-90. CrossRef Medline

Striebel JF, Race B, Chesebro B (2013a) Prion protein and susceptibility to kainate-induced seizures: genetic pitfalls in the use of PrP knockout mice. Prion 7:280-285. CrossRef Medline

Striebel JF, Race B, Pathmajeyan M, Rangel A, Chesebro B (2013b) Lack of influence of prion protein gene expression on kainate-induced seizures in mice: studies using congenic, coisogenic and transgenic strains. Neuroscience 238:11-18. CrossRef Medline

Tamgüney G, Giles K, Glidden DV, Lessard P, Wille H, Tremblay P, Groth DF, Yehiely F, Korth C, Moore RC, Tatzelt J, Rubinstein E, Boucheix C, Yang X, Stanley P, Lisanti MP, Dwek RA, Rudd PM, Moskovitz J, Epstein CJ, et al (2008) Genes contributing to prion pathogenesis. J Gen Virol 89:1777-1788. CrossRef Medline

Thellung S, Gatta E, Pellistri F, Corsaro A, Villa V, Vassalli M, Robello M, Florio T (2013) Excitotoxicity through NMDA receptors mediates cerebellar granule neuron apoptosis induced by prion protein 90-231 fragment. Neurotox Res 23:301-314. CrossRef Medline

Trusel M, Cavaccini A, Gritti M, Greco B, Saintot PP, Nazzaro C, Cerovic M, Morella I, Brambilla R, Tonini R (2015) Coordinated regulation of syn- aptic plasticity at striatopallidal and striatonigral neurons orchestrates motor control. Cell Rep 13:1353-1365. CrossRef Medline

Twele F, Töllner K, Brandt C, Löscher W (2016) Significant effects of sex, strain, and anesthesia in the intrahippocampal kainate mouse model of mesial temporal lobe epilepsy. Epilepsy Behav 55:47-56. CrossRef Medline

Um JW, Nygaard HB, Heiss JK, Kostylev MA, Stagi M, Vortmeyer A, Wisniewski T, Gunther EC, Strittmatter SM (2012) Alzheimer amyloid-beta oligomer bound to postsynaptic prion protein activates Fyn to impair neurons. Nat Neurosci 15:1227-1235. CrossRef Medline

Vezzani A, Viviani B (2015) Neuromodulatory properties of inflammatory cytokines and their impact on neuronal excitability. Neuropharmacology 96:70-82. CrossRef Medline

Vezzani A, Conti M, De Luigi A, Ravizza T, Moneta D, Marchesi F, De Simoni MG (1999) Interleukin-1 $\beta$ immunoreactivity and microglia are enhanced in the rat hippocampus by focal kainate application: functional evidence for enhancement of electrographic seizures. J Neurosci 19:50545065. Medline

Vezzani A, Moneta D, Conti M, Richichi C, Ravizza T, De Luigi A, De Simoni MG, Sperk G, Andell-Jonsson S, Lundkvist J, Iverfeldt K, Bartfai T (2000) Powerful anticonvulsant action of IL-1 receptor antagonist on intracerebral injection and astrocytic overexpression in mice. Proc Natl Acad Sci U S A 97:11534-11539. CrossRef Medline

Viviani B, Bartesaghi S, Gardoni F, Vezzani A, Behrens MM, Bartfai T, Binaglia M, Corsini E, Di Luca M, Galli CL, Marinovich M (2003) Interleukin-1 $\beta$ enhances NMDA receptor-mediated intracellular calcium increase through activation of the Src family of kinases. J Neurosci 23:8692-8700. Medline

Walz R, Amaral OB, Rockenbach IC, Roesler R, Izquierdo I, Cavalheiro EA, Martins VR, Brentani RR (1999) Increased sensitivity to seizures in mice lacking cellular prion protein. Epilepsia 40:1679-1682. CrossRef Medline

Wieser HG, Schindler K, Zumsteg D (2006) EEG in Creutzfeldt-Jakob disease. Clin Neurophysiol 117:935-951. CrossRef Medline

Zhang L, Kirschstein T, Sommersberg B, Merkens M, Manahan-Vaughan D, Elgersma Y, Beck H (2005) Hippocampal synaptic metaplasticity requires inhibitory autophosphorylation of $\mathrm{Ca}^{2+} /$ calmodulin-dependent kinase II. J Neurosci 25:7697-7707. CrossRef Medline 